NBER WORKING PAPER SERIES

\title{
PATTERNS OF CONVERGENCE AND DIVERGENCE IN THE EURO AREA
}

\author{
Ángel Estrada \\ Jordi Galí \\ David López-Salido \\ Working Paper 19561 \\ http://www.nber.org/papers/w19561 \\ NATIONAL BUREAU OF ECONOMIC RESEARCH \\ 1050 Massachusetts Avenue \\ Cambridge, MA 02138 \\ October 2013
}

Prepared for the IMF Thirteenth Jacques Polak Annual Research Conference, November 89, 2012. We thank Pierre-Olivier Gourinchas, Ayhan Kose, and two anonymous referees and conference participants for their comments. The views expressed in this paper are those of the authors alone and do not necessarily reflect the views of the Banco de España, the Board of Governors of the Federal Reserve System, its staff, or the National Bureau of Economic Research.

At least one co-author has disclosed a financial relationship of potential relevance for this research. Further information is available online at http://www.nber.org/papers/w19561.ack

NBER working papers are circulated for discussion and comment purposes. They have not been peerreviewed or been subject to the review by the NBER Board of Directors that accompanies official NBER publications.

(C) 2013 by Ángel Estrada, Jordi Galí, and David López-Salido. All rights reserved. Short sections of text, not to exceed two paragraphs, may be quoted without explicit permission provided that full credit, including $(\mathbb{C}$ notice, is given to the source. 
Patterns of Convergence and Divergence in the Euro Area Ángel Estrada, Jordi Galí, and David López-Salido

NBER Working Paper No. 19561

October 2013

JEL No. E24,F31,O47

\section{ABSTRACT}

We study the extent of macroeconomic convergence/divergence among euro area countries. Our analysis focuses on four variables (unemployment, inflation, relative prices and the current account), and seeks to uncover the role played by monetary union as a convergence factor by using non-euro developed economies and the pre-EMU period as control samples

Ángel Estrada

Bank of Spain

Alcala 48

21014 Madrid (Spain)

angel.estrada@bde.es
David López-Salido

Federal Reserve Board

20th and C Streets, N.W.

Washington, DC 20551

david.j.lopez-salido@frb.gov

Jordi Galí

Centre de Recerca en Economia Internacional (CREI)

Ramon Trias Fargas 25

08005 Barcelona

SPAIN

and NBER

jgali@crei.cat 


\section{Introduction}

The creation of the European Monetary Union (EMU) in 1999 was widely expected to become a catalyst for further economic integration and convergence within Europe. But the ongoing sovereign debt crisis and, more generally, the differential macroeconomic performance across euro area members in the aftermath of the financial crisis have called that prediction into question. It has even led some commentators to argue that the adoption of a common currency may have instead been a factor of divergence and, in particular, a source of a growing gap between a "virtuous core" and a "sinful periphery." The goal of the present paper is to assess whether the data supports that view. In particular, we examine the extent of macroeconomic convergence/divergence among euro area countries over the 1999-2012 period, and the role that sharing a common currency may have played in accounting for that evolution. Our analysis focuses on the differential performance across countries of labor markets, as reflected in the unemployment rate, as well as measures of inflation and competitiveness. The relation between price-competitiveness and current account imbalances is also explored, paying special attention to the role played by non price-competitiveness factors. Throughout we treat the performance during the pre-EMU period, as well as the experience of a number of non-euro developed economies, as control samples. ${ }^{2}$

Our main findings can be summarized as follows. The first nine years of EMU witnessed a strong converge in unemployment rates across euro area countries. But both the long-term trends and the extent of the short-term comovement of unemployment rates appear to be shared by other non-euro economies. With the onset of the financial crisis, however, that convergence process among euro area countries has been interrupted and largely reversed, more so than in other non-euro economies.

Secondly, we report strong evidence of convergence towards low inflation rates over the past quarter century, though that convergence seems unrelated to monetary union itself since it has been experienced by most advanced economies. The previous long-term trend notwithstanding, our analysis uncovers persistent inflation differentials within the euro area during the EMU period and, as a result, large cumulative changes in relative prices. Interestingly, though, rather than representing increasingly divergent patterns, those inflation differentials have implied a substantial convergence in price

\footnotetext{
2 Our focus is on macroeconomic convergence. For overview of the impact of EMU on trade and financial integration see, e.g., Lane (2006), Santos-Silva and Tenreyro (2010), and Kalemli-Ozcan et al. (2010).
} 
levels, especially in the case of tradable goods. This feature contrasts with the evidence regarding other developed economies.

Thirdly, we point to the presence of large differences in the evolution of the current account balance across euro area countries. Perhaps more surprisingly, those differences seem to display little relation with "narrow" measures of competitiveness, as represented by relative price levels of tradable goods. Instead they seem to bear a stronger relation with broader, non-price competitiveness factors. A possible implication of that finding is that internal devaluation policies may have limited success in the medium run at reducing external imbalances unless accompanied by structural reforms that boost some of those non-price factors.

The remainder of the paper is organized as follows. In Section 2, we analyze the behavior of the unemployment rate. Section 3 considers the degree of nominal convergence, as reflected in inflation differentials. Section 4 examines the evolution of relative prices, distinguishing between tradable and non-tradable sectors. The relationship between price-competitiveness and the current account is explored in Section 5 of the paper, which also introduces other nonprice components of competitiveness. The final section summarizes the main results and concludes.

\section{Patterns of Convergence of Unemployment Rates in the Euro}

\section{Area}

As of April 2013, the unemployment rate in the euro area was holding at 12.1\%, almost five percentage points higher than in March 2008, when it had reached a record low since the start of EMU. The aggregate unemployment rate, however, conceals huge differences across countries, as brought out in Figure 1. The lowest unemployment rates can be observed in Austria (4.8\%) and Germany $(5.4 \%)$, while the highest are found in Greece $(26.9 \%)$ and Spain $(26.8 \%)$. Thus, the range of unemployment rates is above 20 percentage points. The standard deviation is $6.6 \%$. 




Figure 1. Unemployment Rate in Euro Area Countries (April 2013)

The large dispersion in unemployment rates is likely due to several factors, including the presence of asymmetric shocks and/or propagation mechanisms, the limited labor mobility within the euro area and the lack of a fiscal union that could act as a stabilizing risk-sharing device in the face of country-specific shocks. Factors of this sort are often viewed as making the euro area fall short of an optimal currency area. ${ }^{3}$ In that light, it is useful to contrast the evidence above with that of the states in the U.S., another large currency union. Thus, in June 2013, when the U.S. national unemployment rate was 7.6\%, the range of unemployment rates across U.S. states went from 3.1\% in North Dakota and $3.9 \%$ in South Dakota to $9.6 \%$ in Nevada and 9.2\% in Illinois, with a standard deviation of $1.6 \%$. The contrast with the euro area is indeed stark, as reflected in the histogram in Figure 2.

\footnotetext{
${ }^{3}$ Mundell (1961) and Kenen (1969) were among the first to emphasize the importance of those factors in order to determine whether the costs of a currency union (associated to the lack of a country specific monetary policy) would more than offset the benefits (associated with greater trade and financial integration).
} 


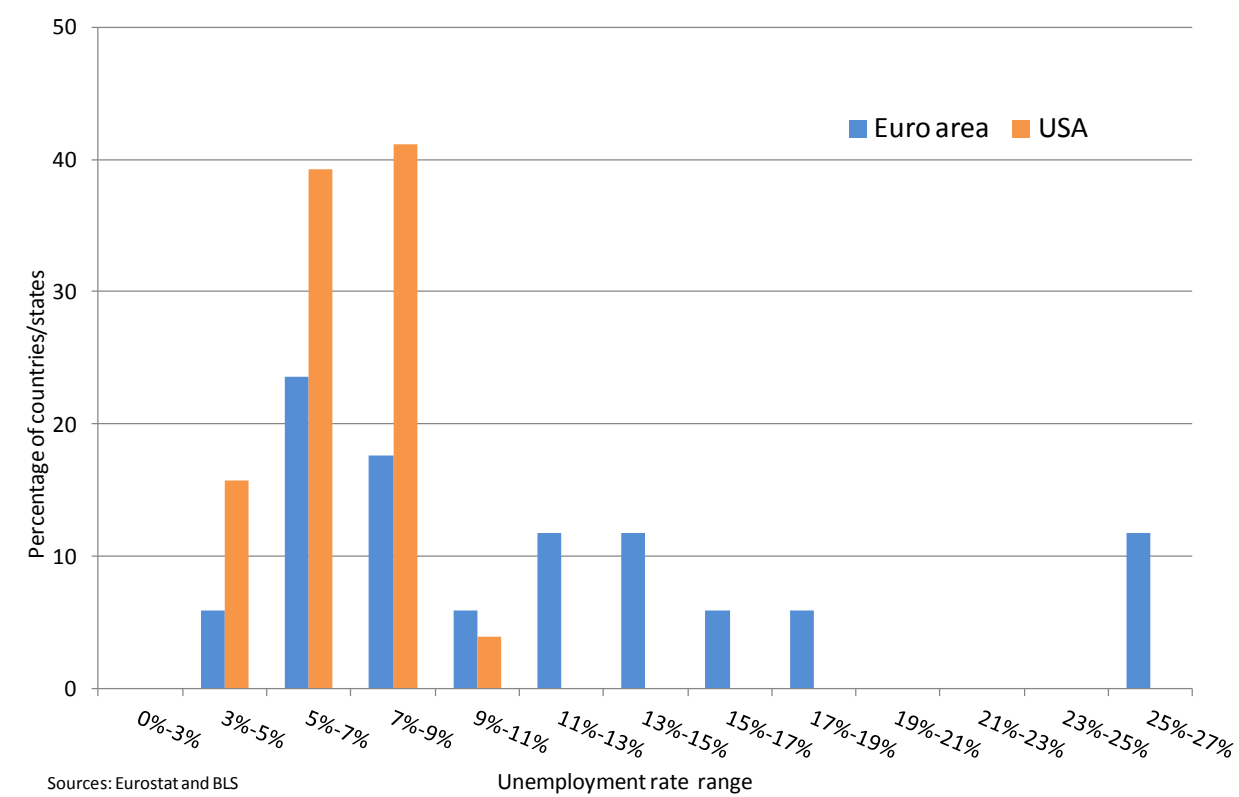

Figure 2. Distribution of Unemployment Rates across Euro Area Countries (April 2013) and US States (June 2013)

Can the large dispersion in unemployment rates across the euro area be attributed to the adoption of the single currency and a common monetary policy? Or has the latter led instead to a more similar labor market performance? In order to address those questions, we begin by looking at the evolution of the unemployment rate in eleven euro area countries: Belgium, Germany, France, Italy, Netherlands, Ireland, Spain, Portugal, Greece, Austria and Finland. We also report evidence for an aggregate (referred to henceforth as EA12) comprising the previous countries plus Luxembourg. We compare the statistics for our set of euro area countries with those of ten other economies, which we use as a control group. The latter includes the United States, Japan, Canada, the United Kingdom, Sweden, Denmark, Switzerland, Australia and New Zealand, as well as the EA12 as a whole. We refer to this group as "other developed economies." For both groups of countries (in the present section as well as for the remainder of the paper) we use annual data spanning the period 1985-2012.

Next we describe some of the patterns of convergence and/or divergence of unemployment rates found in the data, using a few simple graphs.

Figure 3.a displays the unemployment rate for the group of euro area countries in selected years: 1985, 1998 (the year before EMU), 2007 (the last year of expansion), and 2012 (the last year for which we have annual data). The unemployment rate for the EA12-shown in black in Figure 3.a-does not 
display a marked trend over the fourteen years preceding the inception of EMU. But that aggregate pattern masks non-negligible trends in individual countries: some experience large increases in their unemployment rates (most noticeably Finland), while others experience large decreases (e.g. Ireland). A similar "diversity of trends" can be detected for other developed economies in that period, as shown in Figure 3.b. In both cases, however, the different trends worked in the direction of strengthening the convergence in unemployment rates.

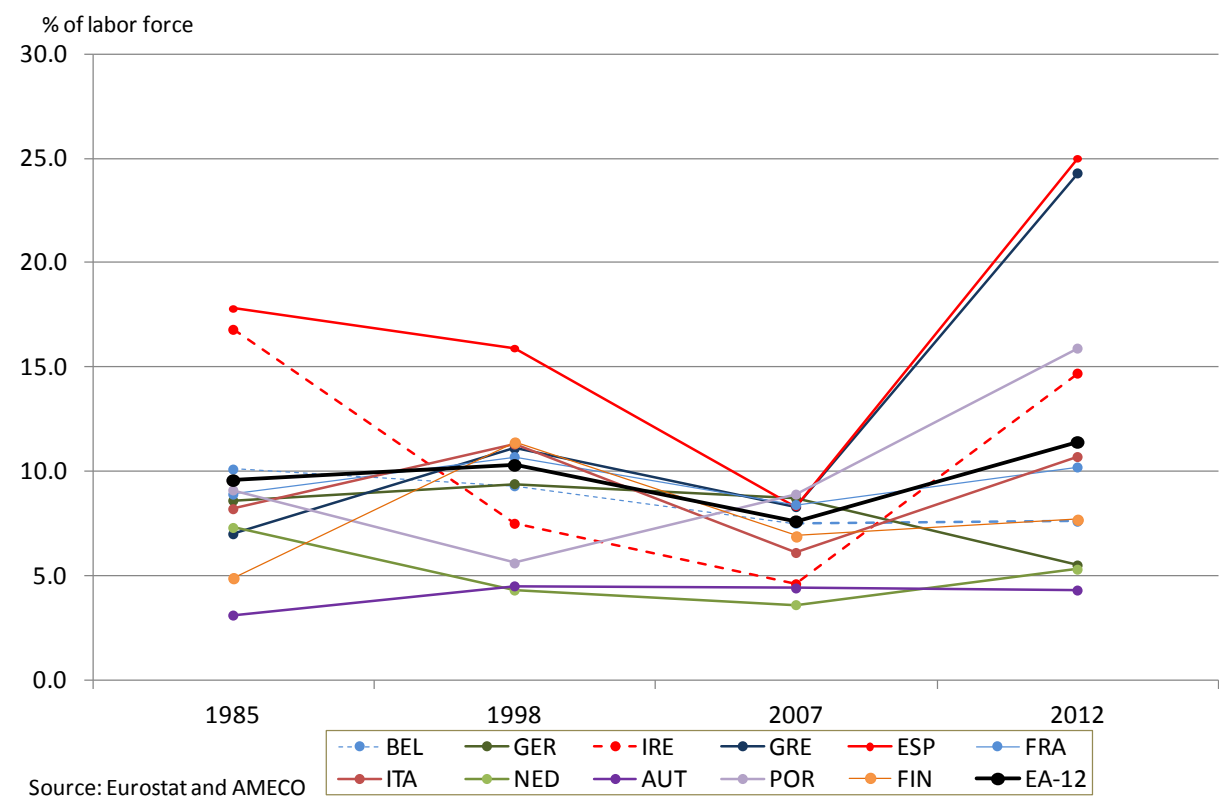

Figure 3.a. Unemployment Rate in Euro Area Countries: Selected Years

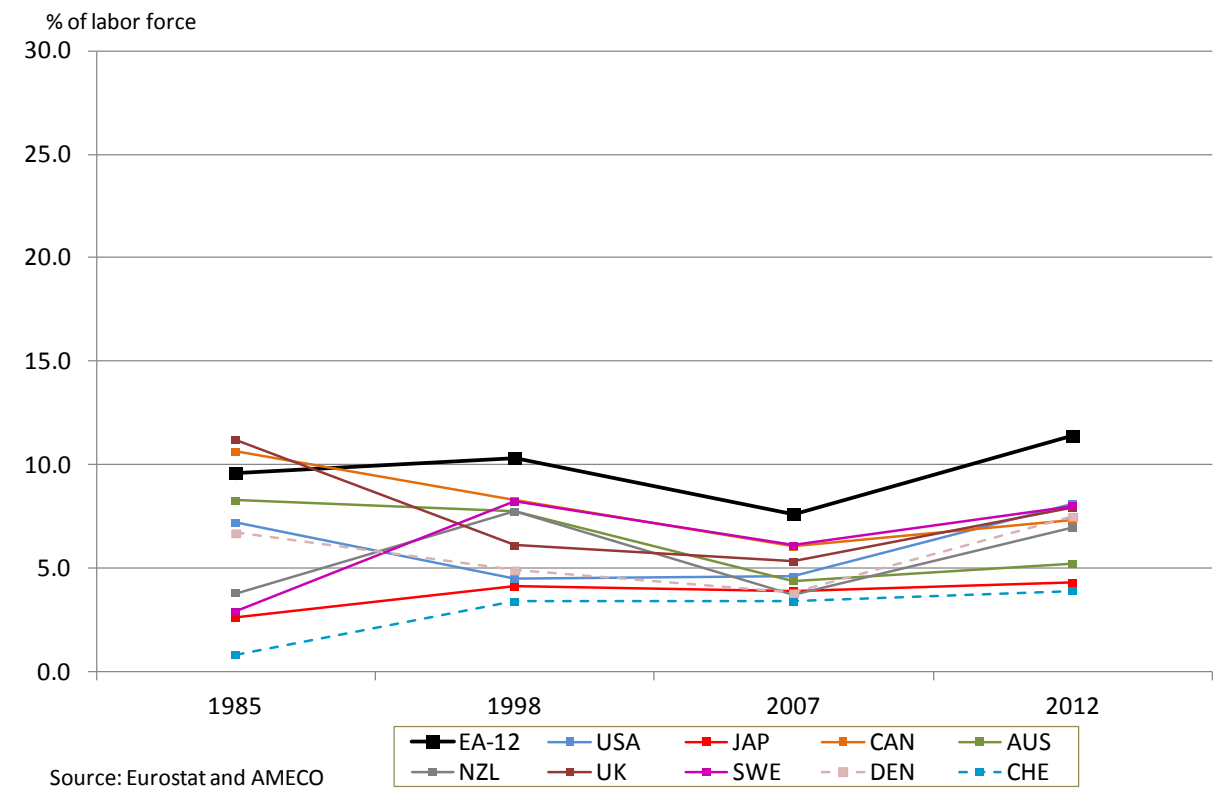

Figure 3.b. Unemployment Rate in Other Developed Countries: Selected Years 
During the expansionary phase of the EMU period (1999-2007), we observe a generalized decline in the unemployment rate of euro area countries (with the exception of Portugal), accompanied by an apparent reduction in the dispersion of that variable. This is also the case among other developed economies.

On the other hand, the period that starts in 2007 is associated with a generalized rise in unemployment. The extent of the rise differs substantially across countries, as is apparent in Figures 3.a and 3.b. Thus, and compared with 2007, the unemployment rate in 2012 was 16.7 percentage points higher in Spain, 16.0 in Greece and 10.1 in Ireland. In contrast, it went down 3.2 percentage points in Germany over the same period. A similar qualitative pattern holds true for the other advanced economies, though the extent of the dispersion is more limited.

Figure 4.a shows the evolution of the cross-sectional standard deviation of the unemployment rate, for the two groups of countries separately. We refer to a reduction in that measure of dispersion for any variable as evidence of " $\sigma$ convergence." Note that the dispersion in unemployment rates is higher in the euro area than in the control group over the entire sample period. Dispersion declines between 1985 until 2007 both in the euro area and in the control group, thus pointing to substantial $\sigma$-convergence during that period. The decline in dispersion was not continuous, however: it was reversed during the recessionary episodes of the early 90 s, and more so among euro area countries. Figure 4.a also suggests that $\sigma$-convergence may have been slightly faster for the euro countries during the EMU years and up to the start of the financial crisis, though starting from larger dispersion levels. As noted above, during that expansionary period $\sigma$-convergence took largely the form of a decline in the unemployment rate everywhere (Portugal being the exception), with a larger decline in countries with a higher initial unemployment rate (Spain being the prime example of that phenomenon). The dispersion of unemployment rates across euro area countries has gone up dramatically since 2008, much more so than for the control group (which also displays a small rise), and it has attained levels exceeding those prevailing anytime since 1985. It is worth mentioning that during the recessionary episode of the early 90s, dispersion increased during three consecutive years (1991-1993), instead of the (at least) five years registered during the current recession. 


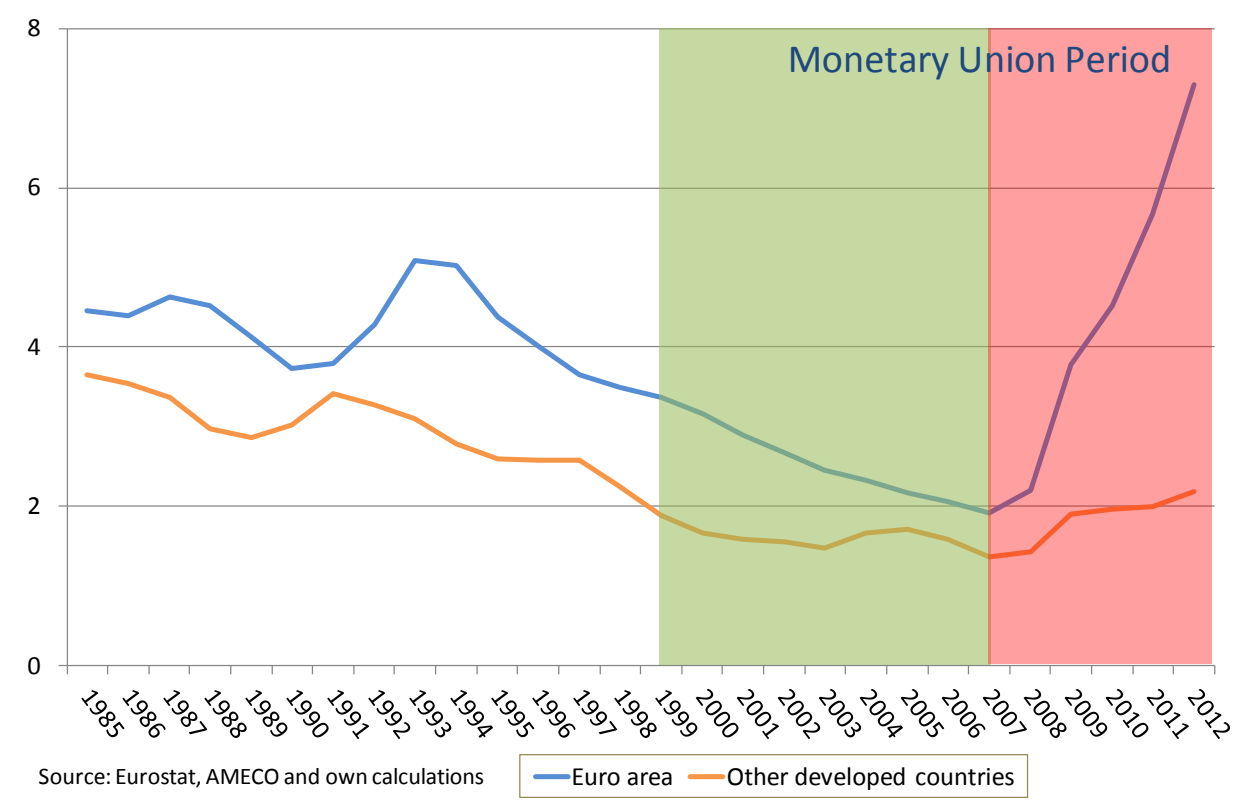

Figure 4.a Dispersion of Unemployment Rates

Changes in the dispersion of unemployment rates discussed above are likely to capture the extent of convergence/divergence in both the structural and cyclical components of unemployment. In order to isolate the cyclical component and, hence, assess the evolution of the degree of cyclical synchronization across countries using that variable, we have also computed the cross-country dispersion in the first-difference of the unemployment rate. We report the corresponding time series for both groups of countries in Figure 4.b. Interestingly, the overall pattern is not too different from that observed in Figure 4.a (though the sign of the gap is no longer uniform). In particular, the degree of dispersion appears to increase in recessionary periods, most dramatically in the case of euro area countries during the most recent crisis episode. Yet, leaving the latter episode aside, it is hard to see any major differences across the two groups of countries, both in the levels and the trends of dispersion, suggesting a limited role of monetary unification in strengthening the degree of cyclical synchronization, at least as measured by our unemployment-based indicator. The previous evidence is largely consistent with recent studies of changes in the degree of cyclical comovement within the euro area during the EMU years. ${ }^{4}$

\footnotetext{
${ }^{4}$ See, e.g., Giannone et al. (2010) and the references therein for evidence on the role of monetary unification as a potential source of greater synchronization of business cycles.
} 


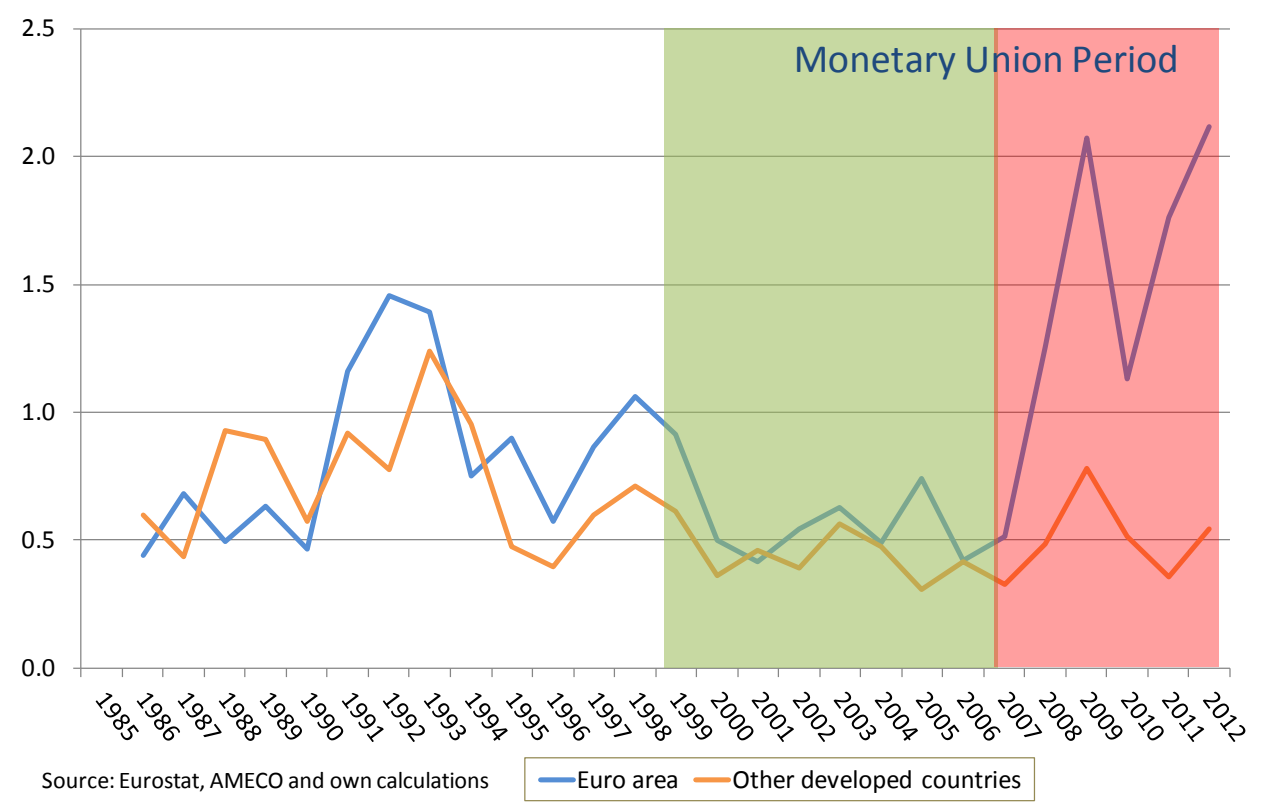

Figure 4.b Dispersion of Unemployment Rates (First-Differences)

Figures 5 shows a scatterplot of the change in the unemployment rate against its initial level for three different sample periods, together with the estimates of regression slopes (separate for each group of countries, shown in different colors). We use the term " $\beta$-convergence" to refer to the existence of a significant negative relation between the initial levels and subsequent changes in a variable. The evidence displayed in Figure 5 reinforces some of the findings discussed above. Thus, in the period before EMU (Figure 5.a) as well as during the expansionary 1999-2007 period (Figure 5.b), we see evidence of substantial $\beta$-convergence in unemployment rates, both in the euro area and outside. The rate of convergence is similar, both across periods and across groups, as reflected in similar slopes. The previous pattern is broken during the 2008-2012 period, for which there is no longer evidence of further $\beta$-convergence. In the case of the euro area this is largely due to Spain and Greece (and to a lesser extent, Portugal), which have experienced the largest increases in the unemployment rate, despite having some of the highest levels of that variable in 2007.5

\footnotetext{
${ }^{5}$ Excluding these three countries, the regression coefficient becomes negative, although nonstatistically significant at standard levels.
} 
a. Pre-EMU Period (1986-1998)

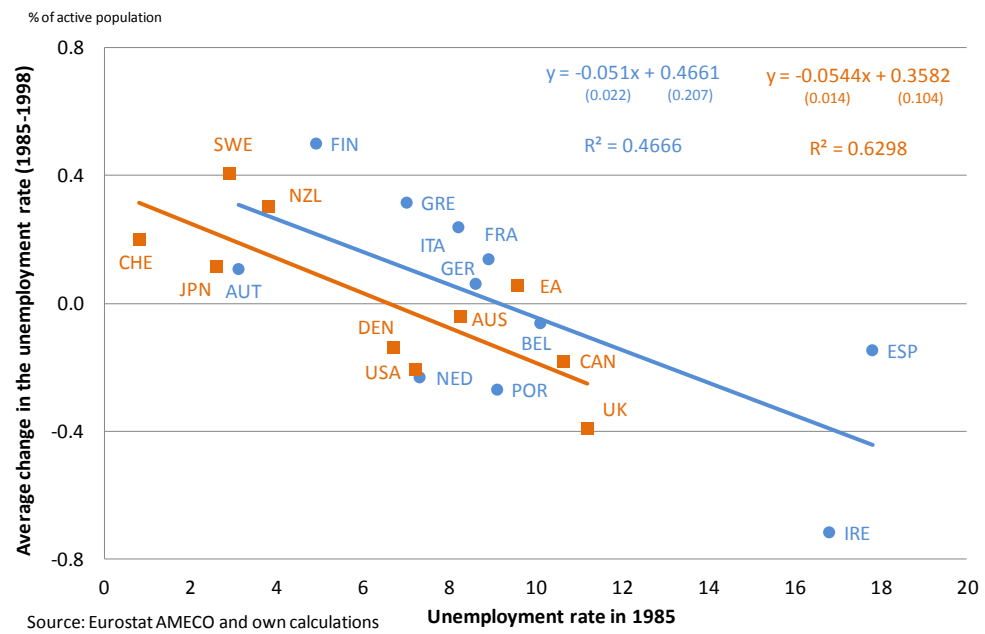

b. EMU Period: Expansion (1999-2007)

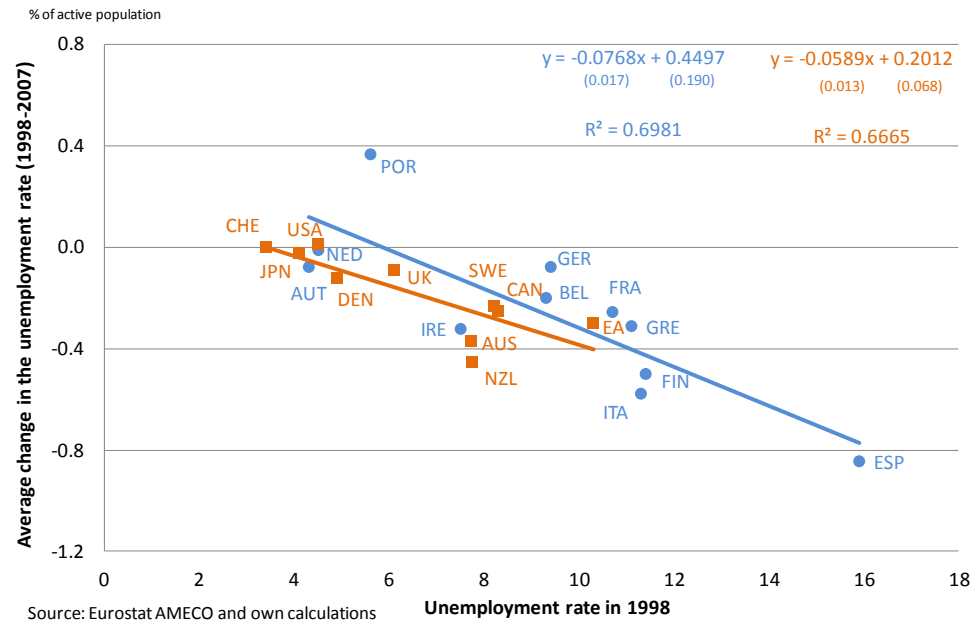

c. EMU Period: Recession (2008-2012)

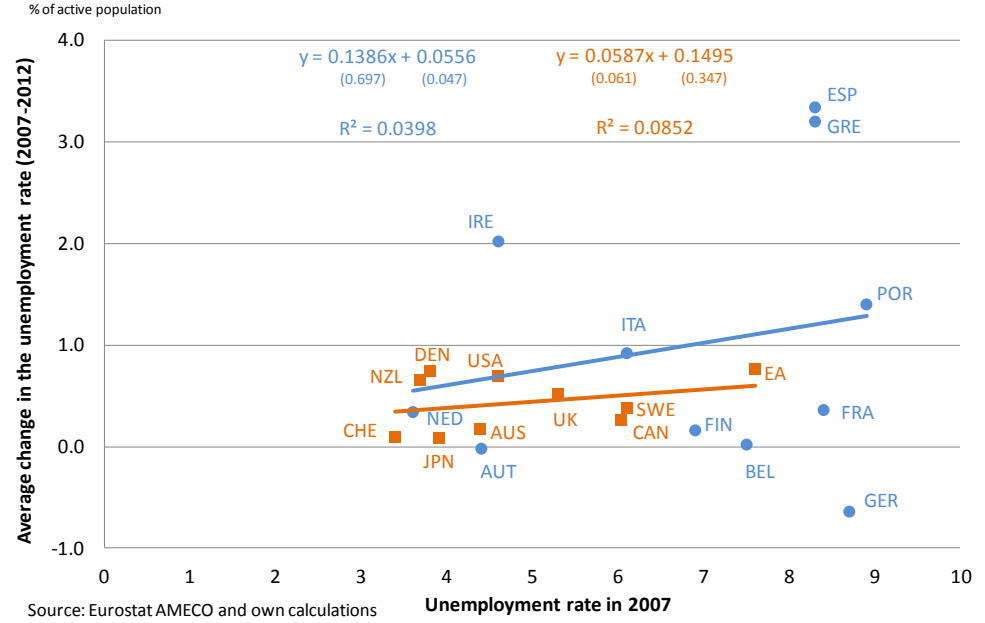

Figure 5. Convergence of Unemployment Rates 
Overall, the evidence reported in this section suggests that EMU in its initial design has had no significant impact on the process of convergence of unemployment rates across euro area countries. That process has been underway since 1985 for all advanced economies, not only those in the euro area, being interrupted only by major recessions. Most importantly, EMU has not prevented a dramatic surge in the dispersion of unemployment rates within the euro area during the recent crisis. The fact that the increase in dispersion across euro area countries has been much larger than for non-euro countries is consistent with the hypothesis that the common currency jointly with the lack of stabilizing risk-sharing devices may have been a factor behind the large differences in unemployment performance.

\section{Patterns of Convergence of Inflation in the Euro Area}

Figure 6 shows the average annual rate of inflation over the 1999-2012 period for eleven euro area countries (plus the EA12), as measured by the average percent change in the harmonized index of consumer prices (HICP). Note that annual HICP inflation for the EA12 over this period is $2 \%$, which coincides with the upper threshold of the inflation target range set by ECB. Differences across countries are, however, substantial, with Germany $(1.6 \%)$ and Greece (3\%) at the opposite ends of the spectrum. The cross-sectional standard deviation is $0.4 \% .^{6}$

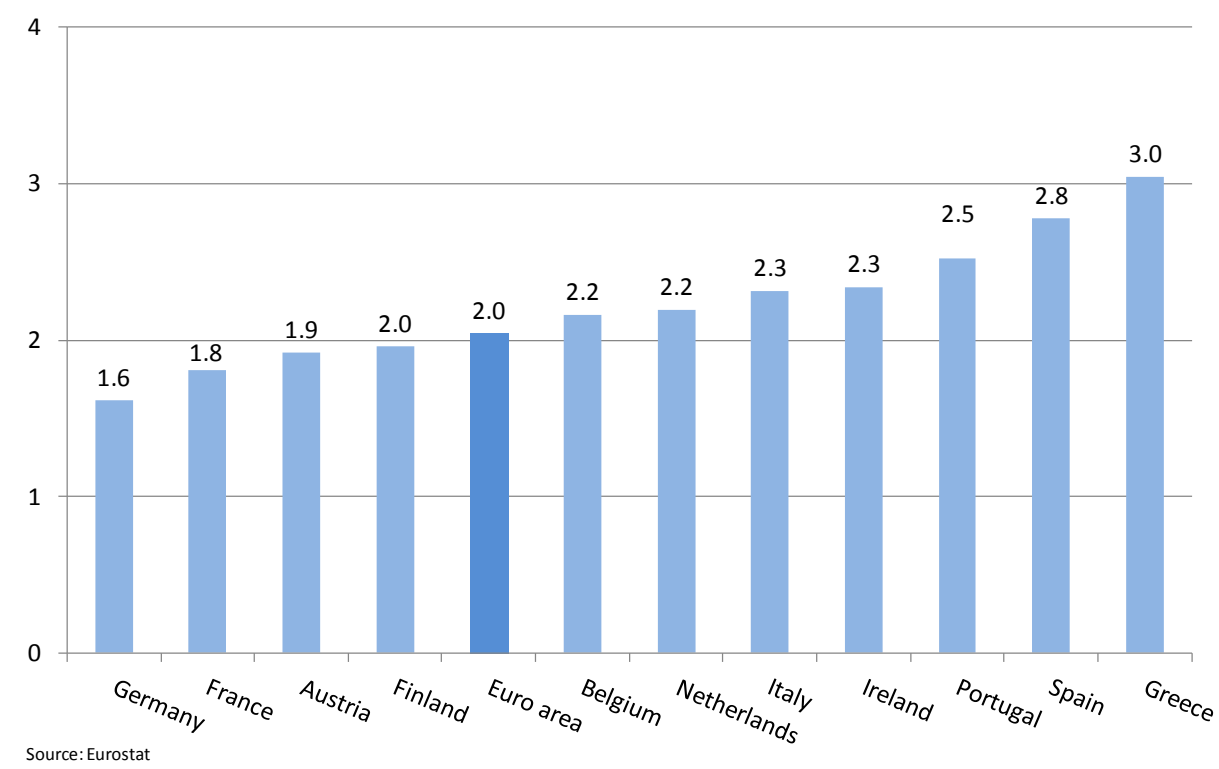

Figure 6. Average Annual Inflation in Euro Area Countries (1999-2012)

\footnotetext{
${ }^{6}$ See Lane (2006) and Mongelli and Wyplosz (2009) for further discussion of inflation differentials and their implications.
} 
The size of inflation differentials across euro area countries during the EMU years pales when compared with those observed before EMU. In fact, as shown in Figure 7.a the process of "nominal" convergence across euro area countries between the mid 1980s and 1998 was substantial. This is also mirrored in the evolution of the cross-sectional standard deviation, shown in Figure 8, which displays evidence of strong $\sigma$-convergence in the pre-EMU years. But, as shown in Figures 7.b and 8, that phenomenon was not restricted to euro area countries, but affected instead most advanced economies. Most likely, thus, it was related to the widespread adoption of monetary policy frameworks stressing central bank independence and explicit inflation targets, and to a lesser extent, by the moderate behavior of commodity prices. ${ }^{7}$ Of course we cannot know whether all current euro area countries would have succeeded in adopting credible monetary policy frameworks consistent with low inflation rates had the monetary integration process not gone underway. ${ }^{8}$



Figure 7.a. Inflation Rate in Euro Area Countries: Selected Years

\footnotetext{
${ }^{7}$ See Caselli (2008) for a related view. Ball and Sheridan (2005) and Mishkin and SchmidtHebbel (2007) provide evidence of a generalized decline in inflation among developed economies over the past quarter century.

8 See Alesina and Barro (2002) for a discussion of the role played by currency unions in overcoming the inflationary bias associated with the time inconsistency problem.
} 


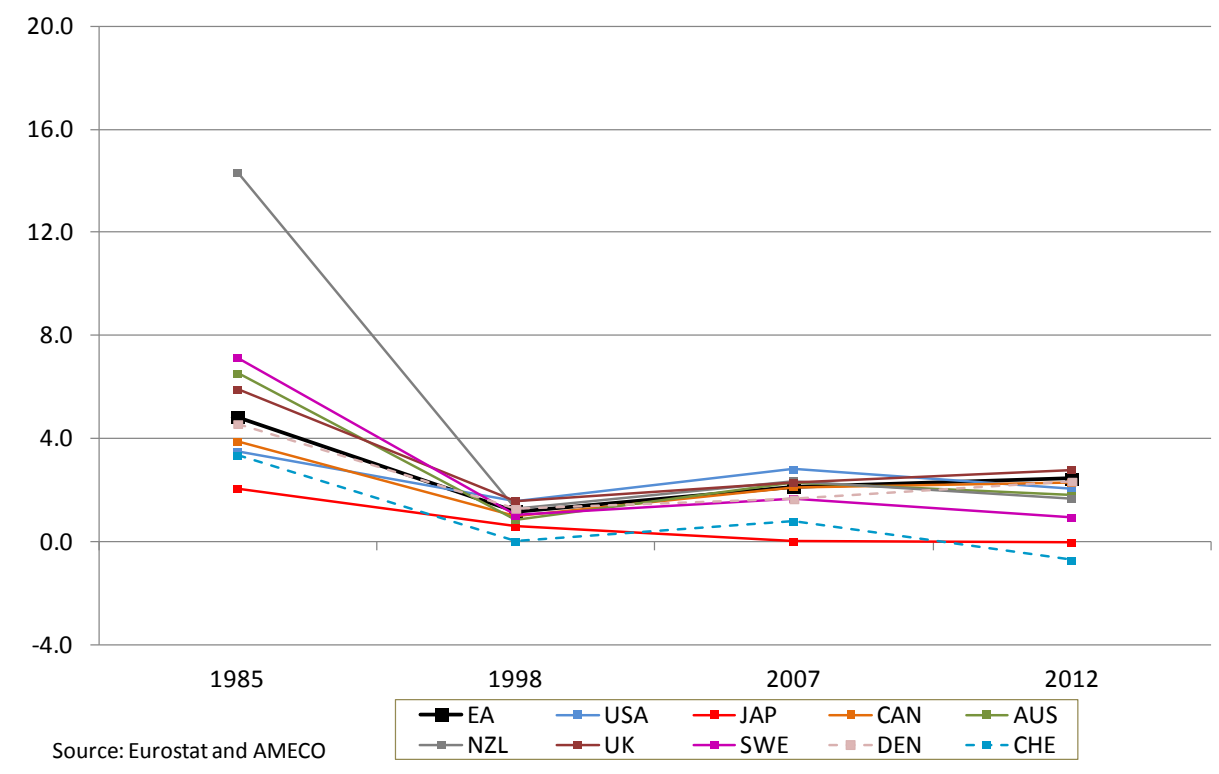

Figure 7.b. Inflation Rate in Other Developed Countries: Selected Years

Furthermore, and as figures 7 and 8 make clear, the bulk of the inflation convergence process took place before the birth of EMU. ${ }^{9}$ Since 1999 inflation dispersion within the euro area has remained quite stable, whereas the corresponding measure for other advanced economies has experienced a mild increase (partly due to deflation in Japan and Switzerland).

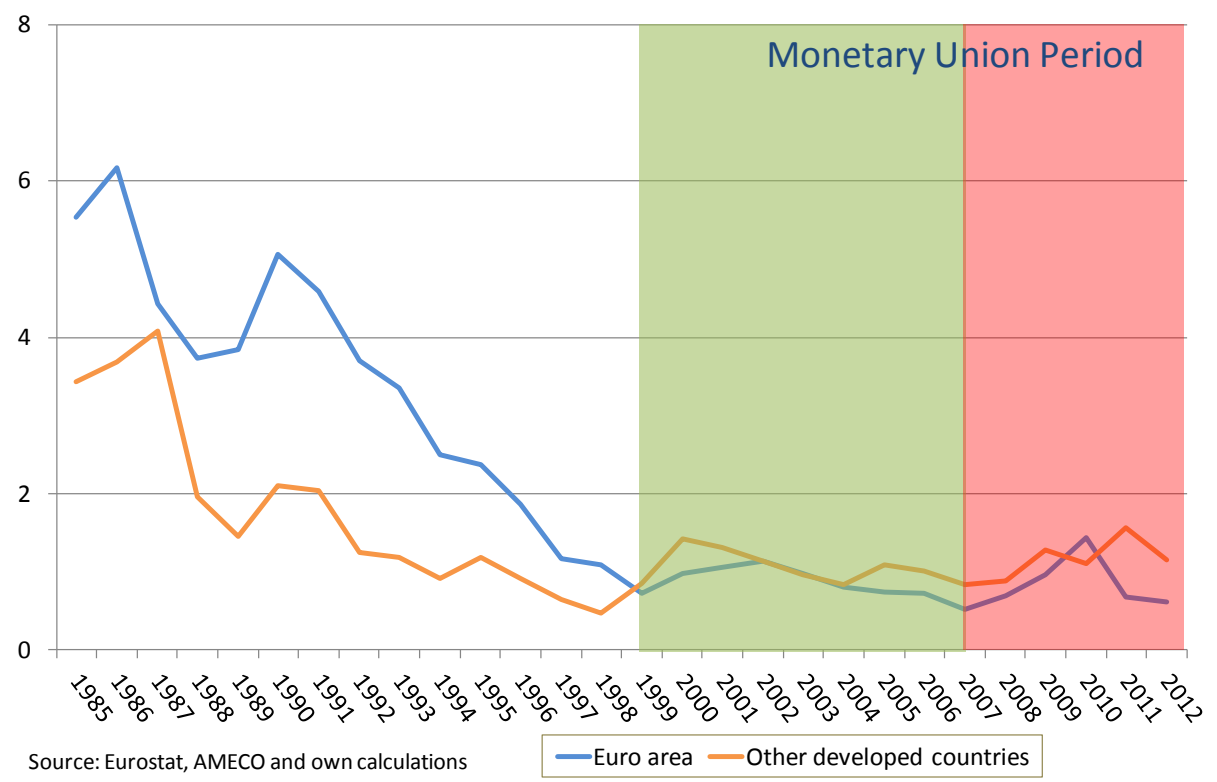

Figure 8. Dispersion of Inflation Rates

\footnotetext{
9 A precondition for EMU membership was that inflation could not be higher than 1.5 percentage points the unweighted average of the three EU member states with the lowest inflation rates.
} 
The scatterplots in Figure 9 and the corresponding $\beta$-convergence regressions shed some additional light on nominal convergence. Both point clearly to the existence of strong $\beta$-convergence in the period before the advent of EMU, across all advanced economies and independently of their eventual membership in the euro area. The rate of convergence across the two groups is also surprisingly similar. Starting in 1999, however, countries within the euro area keep experiencing strong $\beta$-convergence. This is true both during the expansion and the crisis periods, though it appears to have been strengthened in the latter period. This result is reinforced by the fiscal consolidation process implemented by the euro countries (mostly those affected by the financial crisis), as it includes important increases in indirect taxation.

On the other hand, $\beta$-convergence appears to have come to an end after 1999 for advanced economies outside the euro area. Yet, as made clear by Figures 9.b and 9.c, the lack of "reversion to the mean" among the control group is largely due to Japan and Switzerland, which have been stuck with persistently low or negative rates of inflation. ${ }^{10}$

In summary, the evidence in this section suggests that EMU in its initial design has not been a critical factor behind the convergence of inflation rates observed among euro area countries. The reason is that the phenomenon of inflation convergence got underway well before the creation of EMU, and has not been restricted to euro area countries. Furthermore, the operation of EMU does not seem to have strengthened or accelerated that convergence, at least in comparison to other developed economies. ${ }^{10}$ Excluding these two countries form the regression, the convergence parameter becomes
negative, although non-statistically significant at standard levels. 
a. Pre-EMU Period (1986-1998)

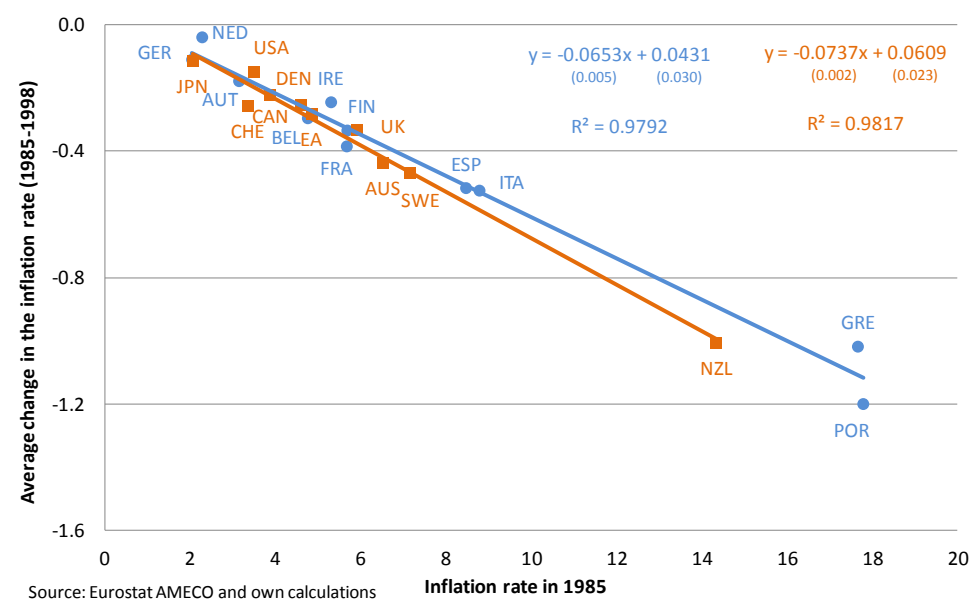

b. EMU Period: Expansion (1999-2007)

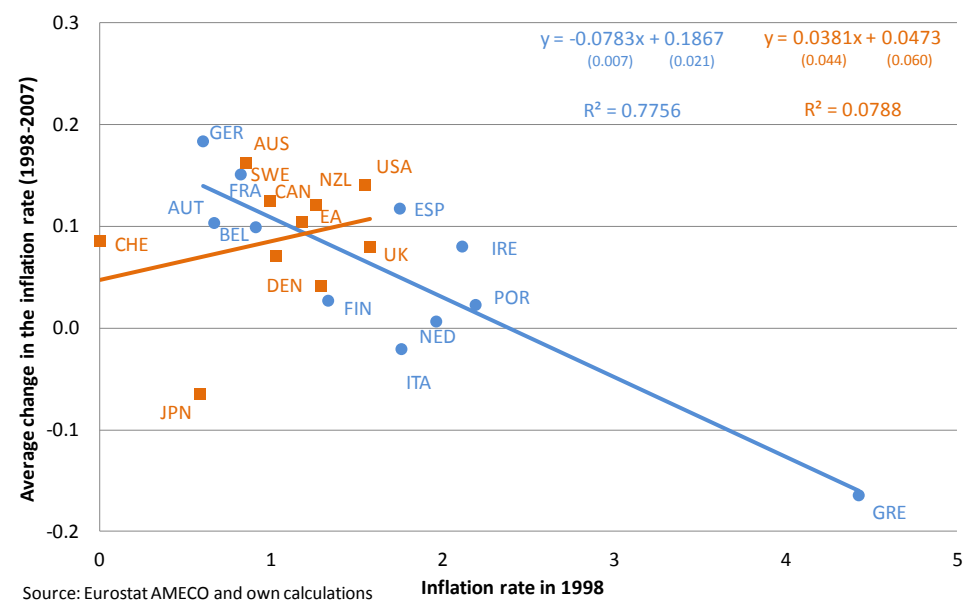

c. EMU Period: Recession (2008-2012)



Figure 9. Convergence of Inflation Rates 


\section{Patterns of Convergence of Relative Price Levels in the Euro}

Area

Figure 10 displays the relative GDP deflators for euro area countries in 2012, with the corresponding level for EA12 normalized to 100. The range between the highest price level (Finland) and the lowest (Portugal) is about 40 percentage points. The standard deviation is $10.8 \%$.

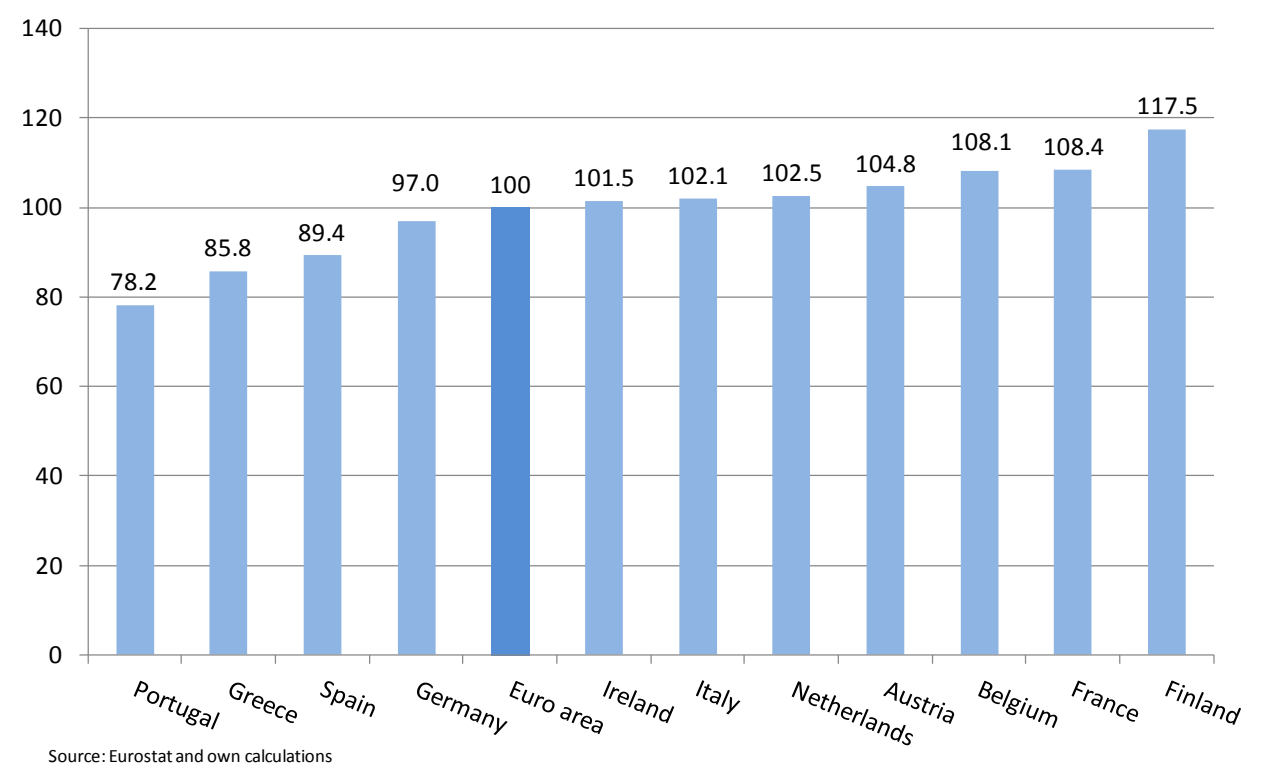

Figure 10. Relative Price Levels in Euro Area Countries (2012, EA12=100)

Figures 11.a and 11.b display the evolution of relative price levels for euro area countries and other developed economies, respectively. In the latter case, price levels are converted to a common currency (the US dollar). In both cases prices are measured relative to the EA12, which is normalized to 100 every period. The evolution of the corresponding dispersion measures is shown in Figure 12. Overall, the data points to a strong process of $\sigma$-convergence within the euro area. The decline in relative price dispersion starts well before the creation of EMU and persists during the EMU period, though it appears to stabilize at a later stage and rise slightly during the recent crisis. On the other hand, the dispersion of relative price levels for other developed economies does not appear to display any marked trends, though it shows non-negligible fluctuations (possibly linked to exchange rate fluctuations). Note also that while dispersion appears to have been greater among euro area countries than among 
other developed economies in the mid 1980s, this is no longer the case since the 1990s. ${ }^{11}$

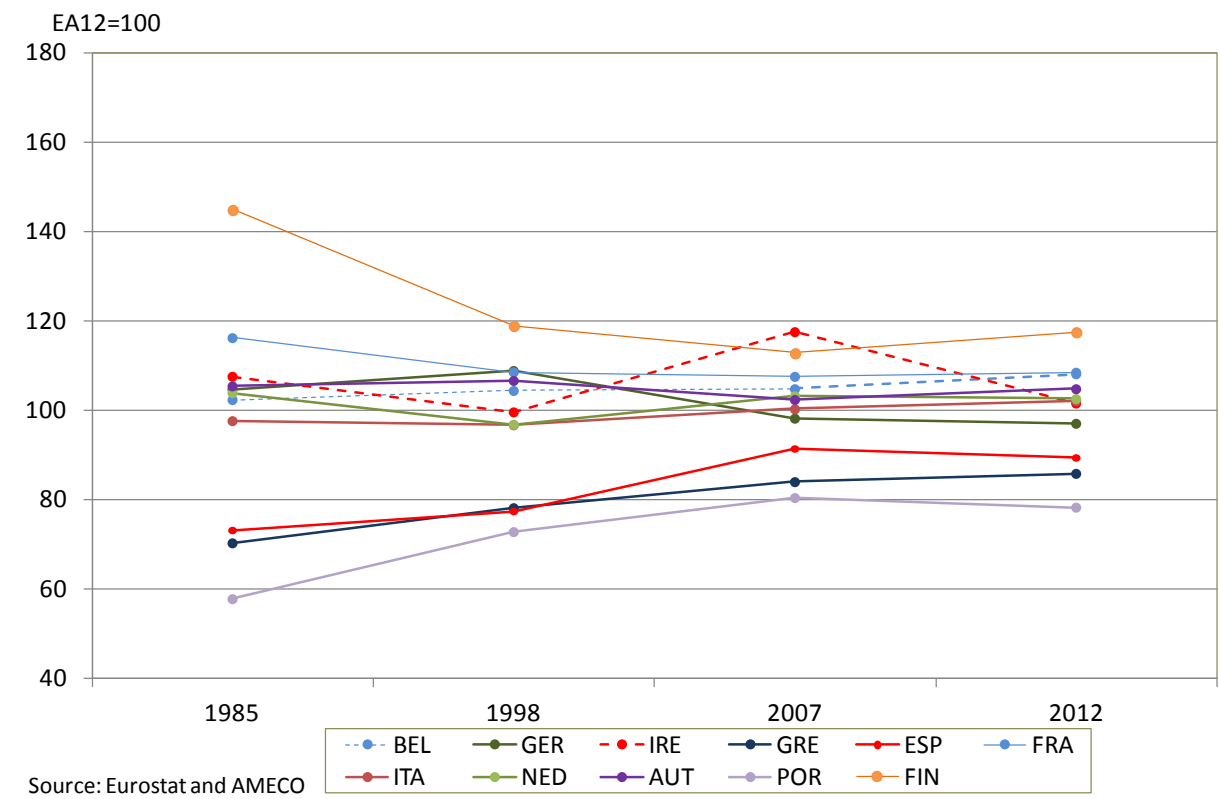

Figure 11.a. Relative Price Levels in Euro Area Countries: Selected Years

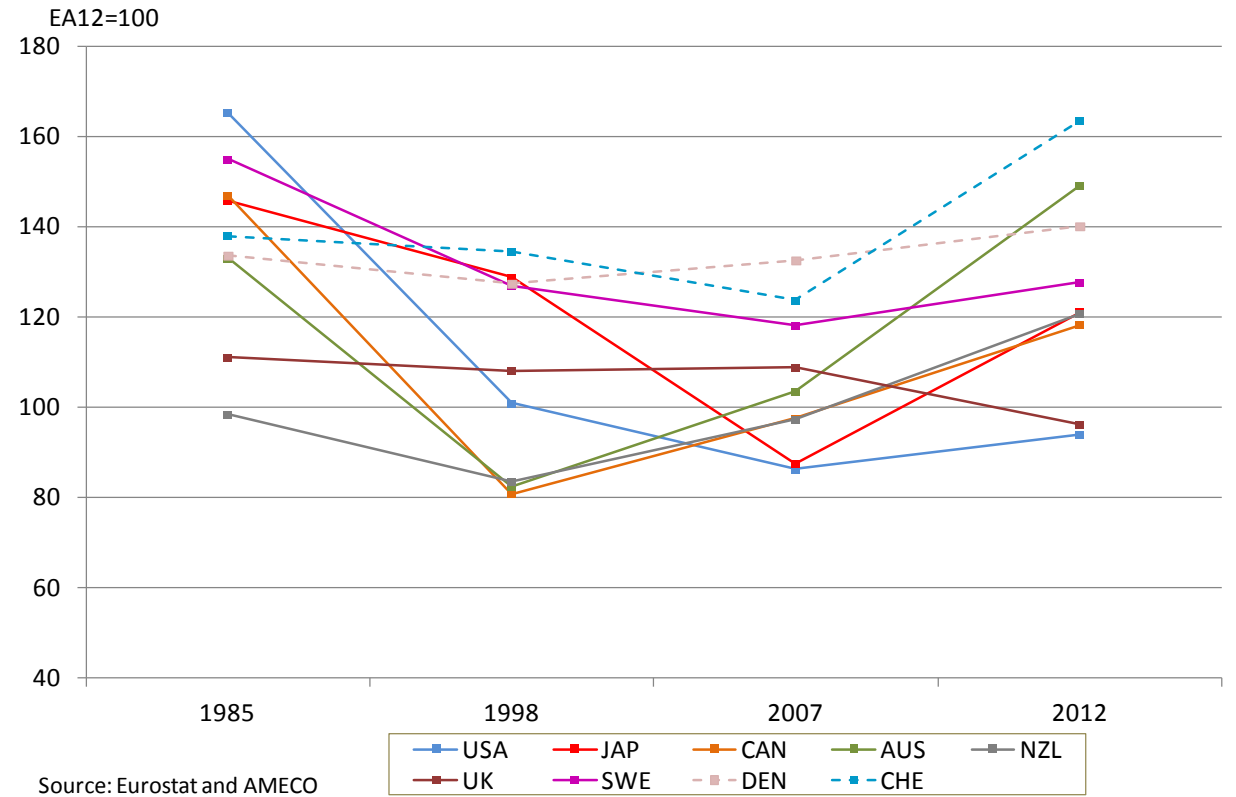

Figure 11.b. Relative Price Levels in Other Developed Countries: Selected Years

${ }^{11}$ See Lane (2006), Engle and Rogers (2004) and Allington et al. (2005) for an analysis of price convergence within the euro area using more disaggregated data. 




Figure 12. Dispersion of Relative Price Levels

Figure 13 points to significant $\beta$-convergence both before and after the creation of the euro area and until the onset of the crisis, and for both groups of countries. Thus, while there is no clear progress in reducing price level differentials across the non-euro economies, there is evidence of significant $\beta$ convergence among those countries, i.e. of some reversion to "average" relative prices. That tendency appears to have been interrupted during the crisis years, as illustrated in Figure 13.c. 
a. Pre-EMU Period (1985-1998)

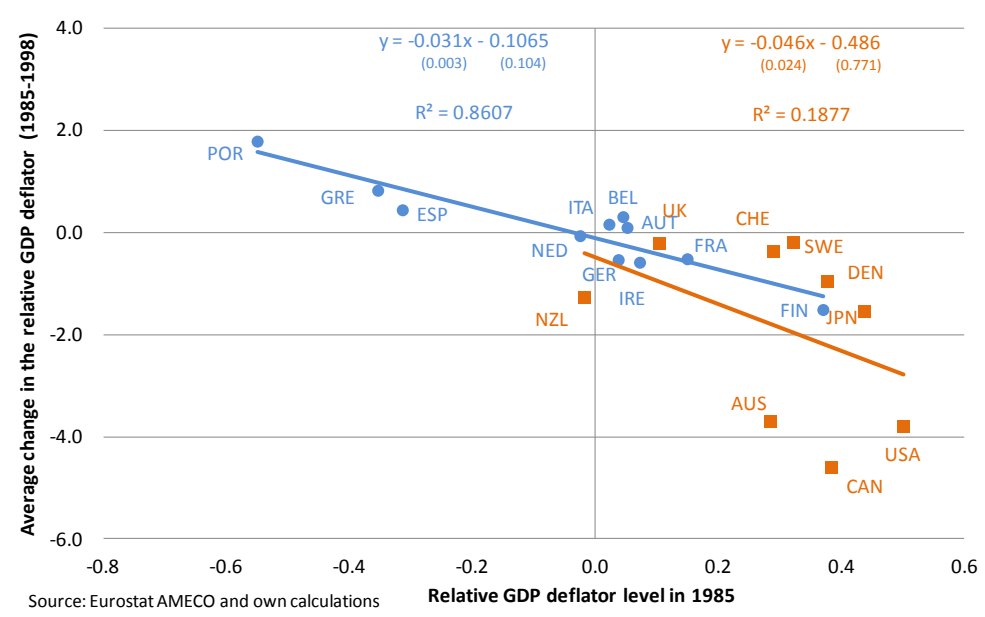

b. EMU Period: Expansion (1999-2007)

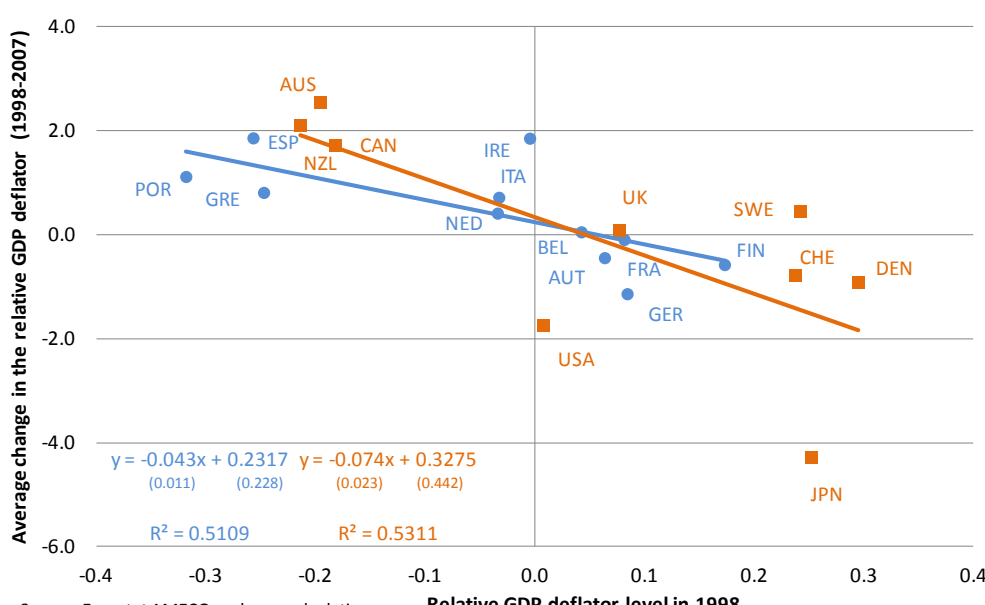

c. EMU Period: Recession (2008-2012)



Figure 13. Convergence of Relative Price Levels 
Figures 14 through 17 present analogous evidence focusing on tradable goods only. A number of observations are worth stressing.

First, as a comparison of Figures 10 and 14 makes clear, the degree of current relative price dispersion within the euro area is much smaller for tradables, as one would expect, with the range between the highest and lowest price levels being of 26 percentage points, as opposed to 40 . In fact, the standard deviation is $8.3 \%, 20$ percent lower than that of GDP deflator. Perhaps most surprisingly, the ranking of relative price levels is considerably different than that for all goods, pointing to a weak cross-country correlation between tradable and nontradable prices.



Figure 14. Relative Price Levels (Tradables) in Euro Area Countries (2012, EA12=100) 


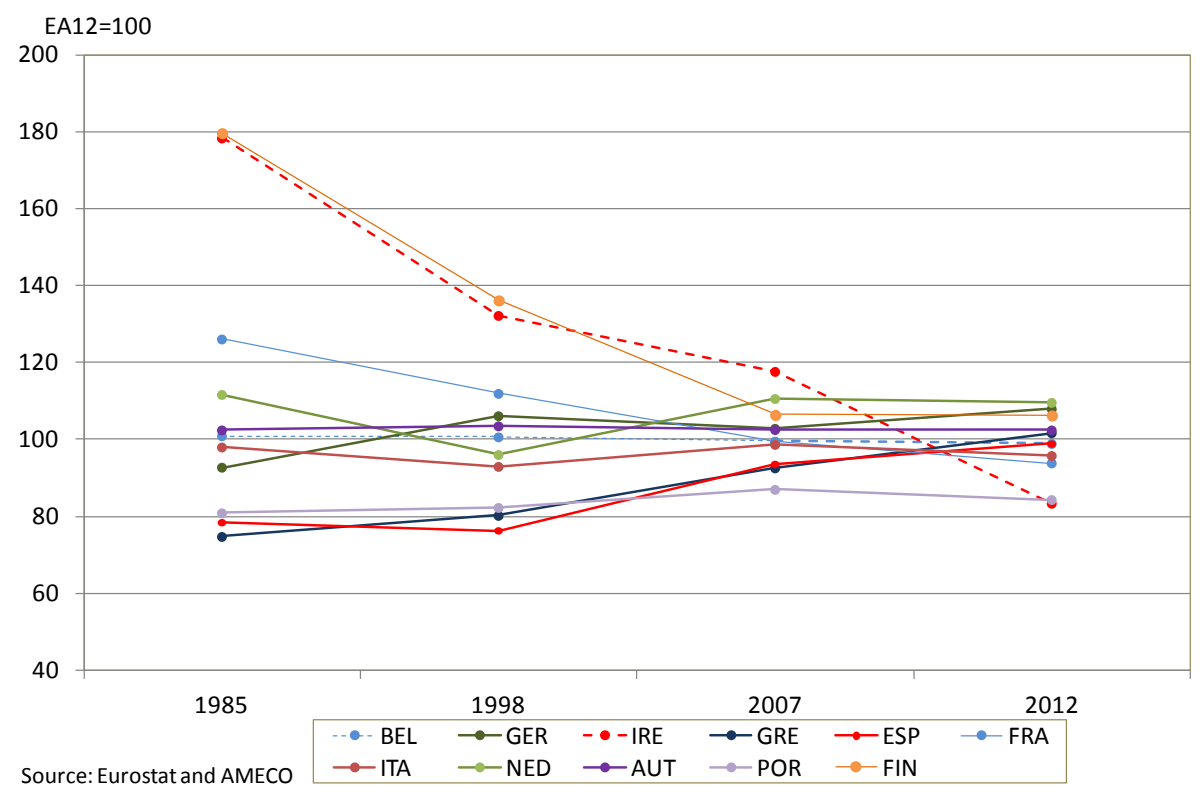

Figure 15.a Relative Price Levels (Tradables) in Euro Area Countries: Selected Years

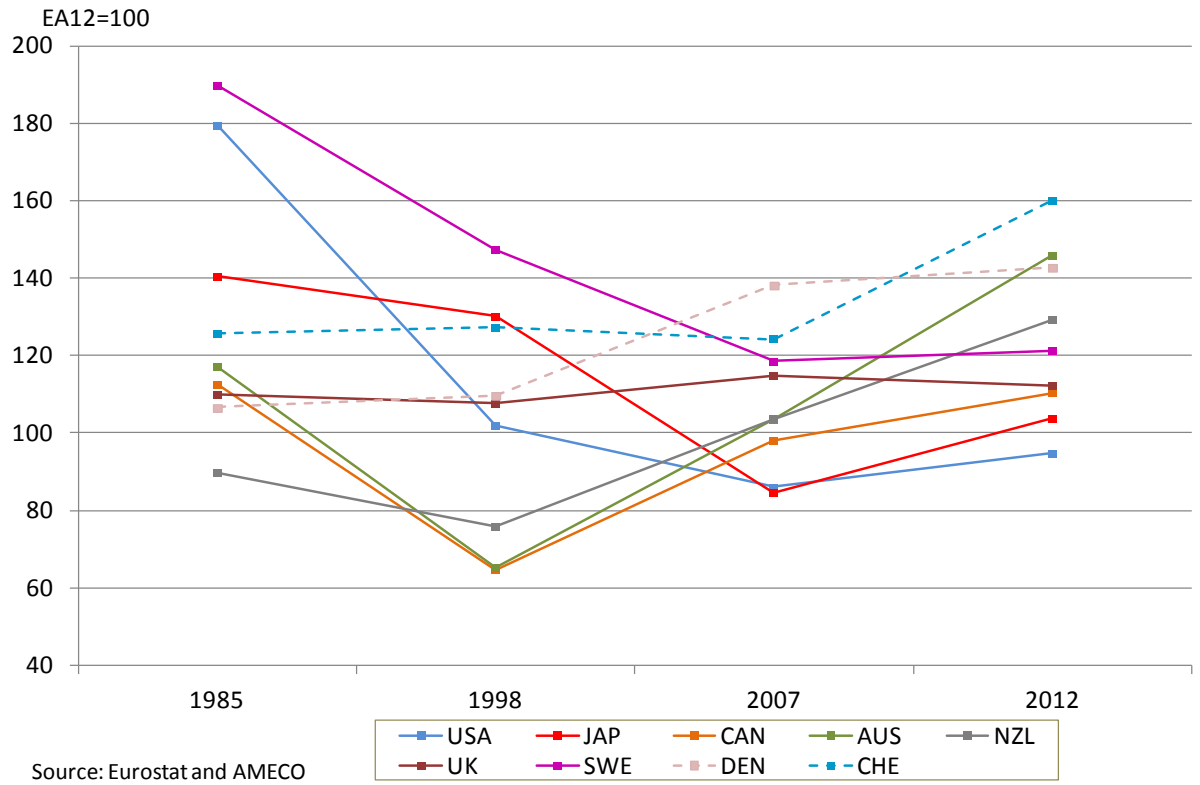

Figure 15.b Relative Price Levels (Tradables) in Other Developed Countries: Selected Years 




Figure 16. Dispersion of Relative Price Levels (Tradables)

Secondly, in the case of tradables there is evidence of $\sigma$-convergence for both groups of countries, and not only for those belonging to the euro zone. That convergence is interrupted and mildly reversed with the advent of the recent crisis. The evidence pertaining to $\beta$-convergence, points to strong convergence for both groups of countries in the pre-EMU as well as the expansionary part of the EMU era, but no longer during the recent crisis episode; this behavior is qualitatively similar to that for all goods and services. 
a. Pre-EMU Period (1985-1998)

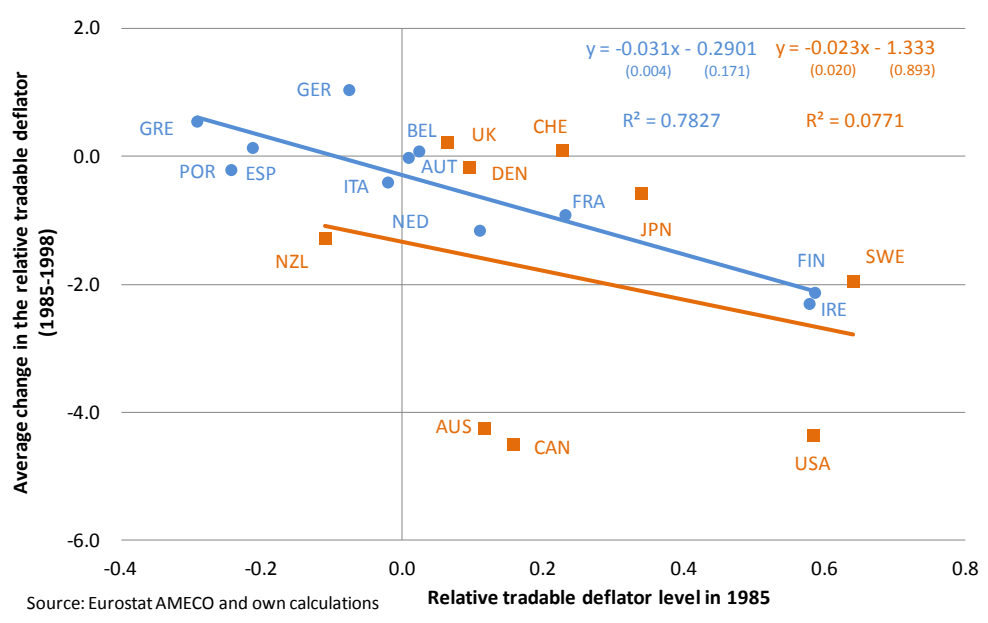

b. EMU Period: Expansion (1999-2007)

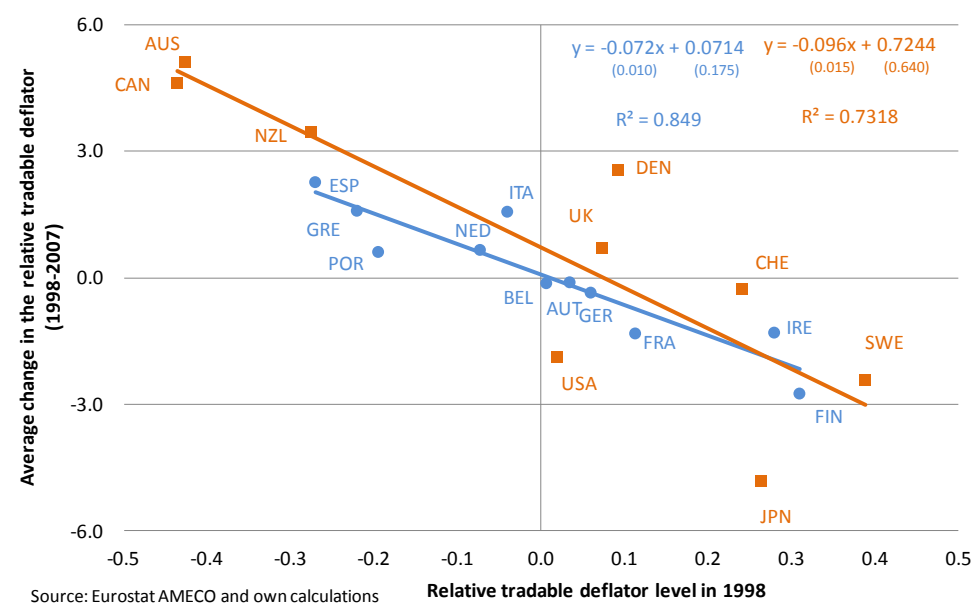

c. EMU Period: Recession (2008-2012)

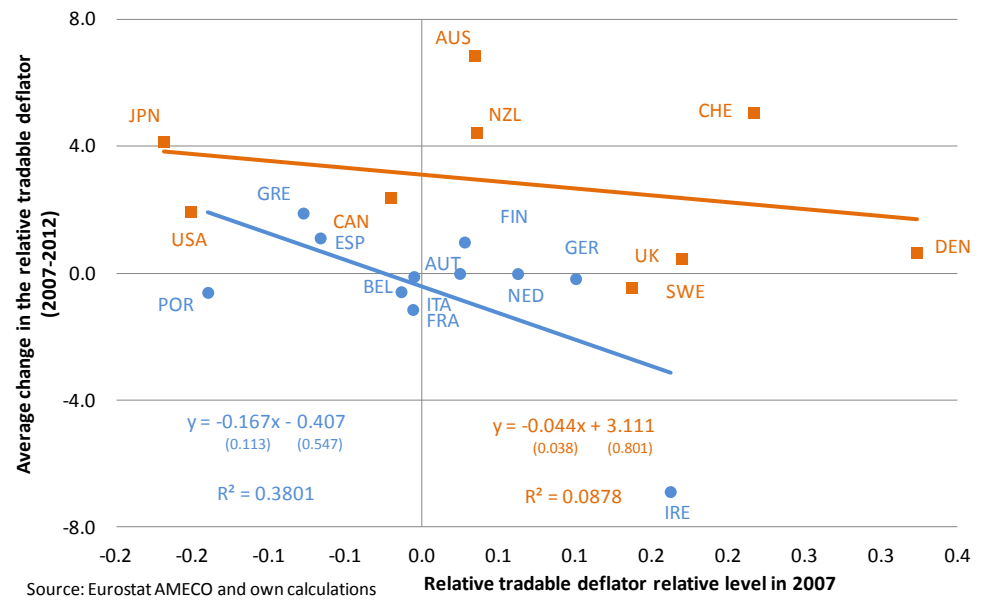

Figure 17. Convergence of Relative Prices (Tradables) 
Overall, the evidence suggests that the patterns of evolution of relative price levels within the euro area have been roughly similar to those observed among other developed economies. In particular, while the dispersion in tradable goods prices is substantially smaller within the euro area, progress in terms of convergence during the EMU years appears to have been stronger among noneuro economies.

\section{Patterns of External Imbalances in the Euro Area: The Role of Price Competitiveness}

Real and nominal convergence within the euro area should have led to a greater convergen ce in the size of external imbalances. In the present section we explore whether this has been so. Up to now, the answer seems to be negative. We try to ascertain the role played by price competitiveness as well as other factors in accounting for the observed divergence.

Figure 18.a summarizes the evolution of current account balances (as a percent of GDP), in the euro area countries. A few observations are worth stressing. First, the size of current account (CA) imbalances experienced by euro area countries was quite moderate in the pre-EMU, though by 1998 three countries were showing substantial imbalances: Portugal (deficit), and Belgium and Finland (surpluses). Second, the EMU era includes two very different episodes. The economic expansion, associated with an important widening of current account imbalances across euro area countries, much more important than that of other developed countries. On the contrary, almost all of this increase in dispersions is reversed between 2007 and 2012 that is the last recession. This suggests an important cyclical pattern underlying this medium-run dynamics. By way of contrast, and as shown in Figure 18.b, the dispersion of current account imbalances among non-euro economies appears to have grown steadily over the past quarter century, but at a slow rate; there was a substantial correction right before the crisis, remaining stable afterwards (see Figure 19).

In fact, it seems that the reduction in the current account imbalances occurs with a certain delay in the euro area relative to the one observed during the crisis in the developed countries. Most of the adjustment took place in the euro zone after 2009, two years after that in the other developed countries (see Figure 19). Finally, is worth noting that most of the contribution to the reduction in the dispersion of the current account imbalances in the euro area is coming from the reduction of the deficits while the surpluses remain at pre-crisis levels. 
These patterns extend beyond these euro-one economies. They are present also in differences between advanced economies (Figure 18.b).

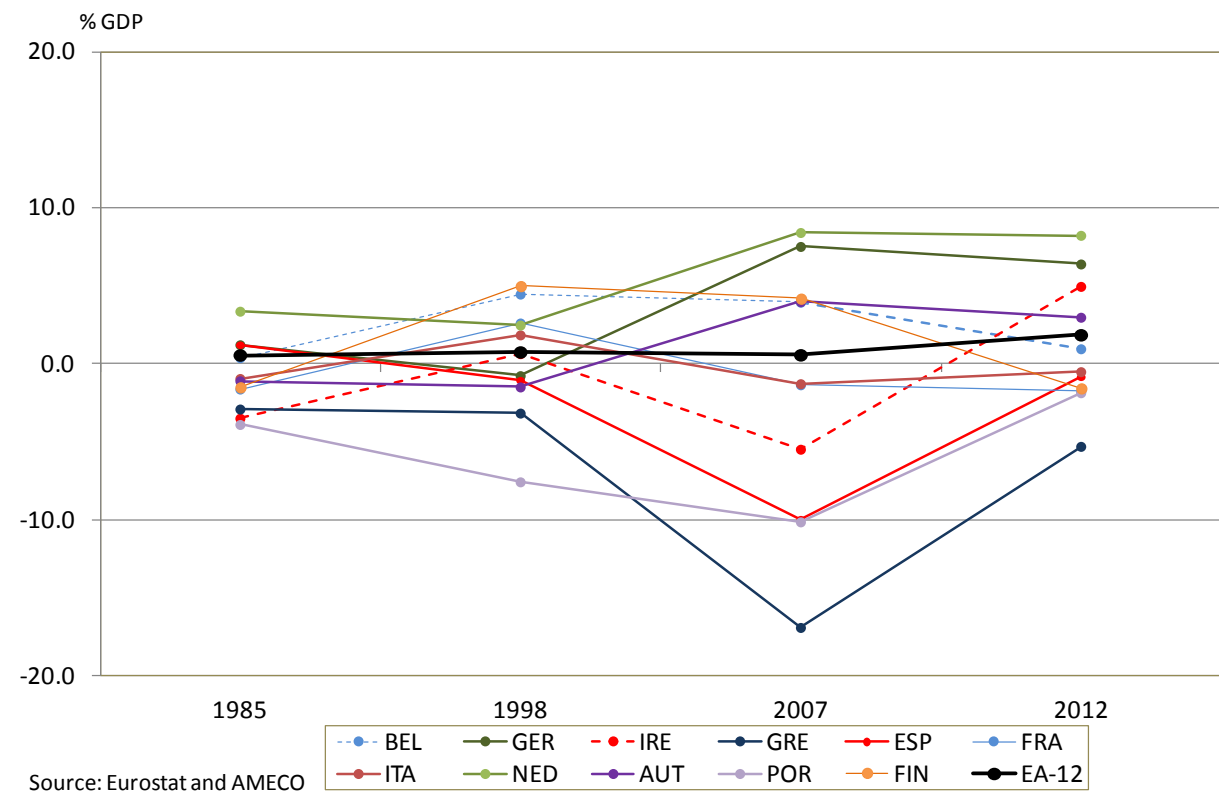

Figure 18.a Evolution of the Current Account (\% of GDP) in Euro Area Countries: Selected Years

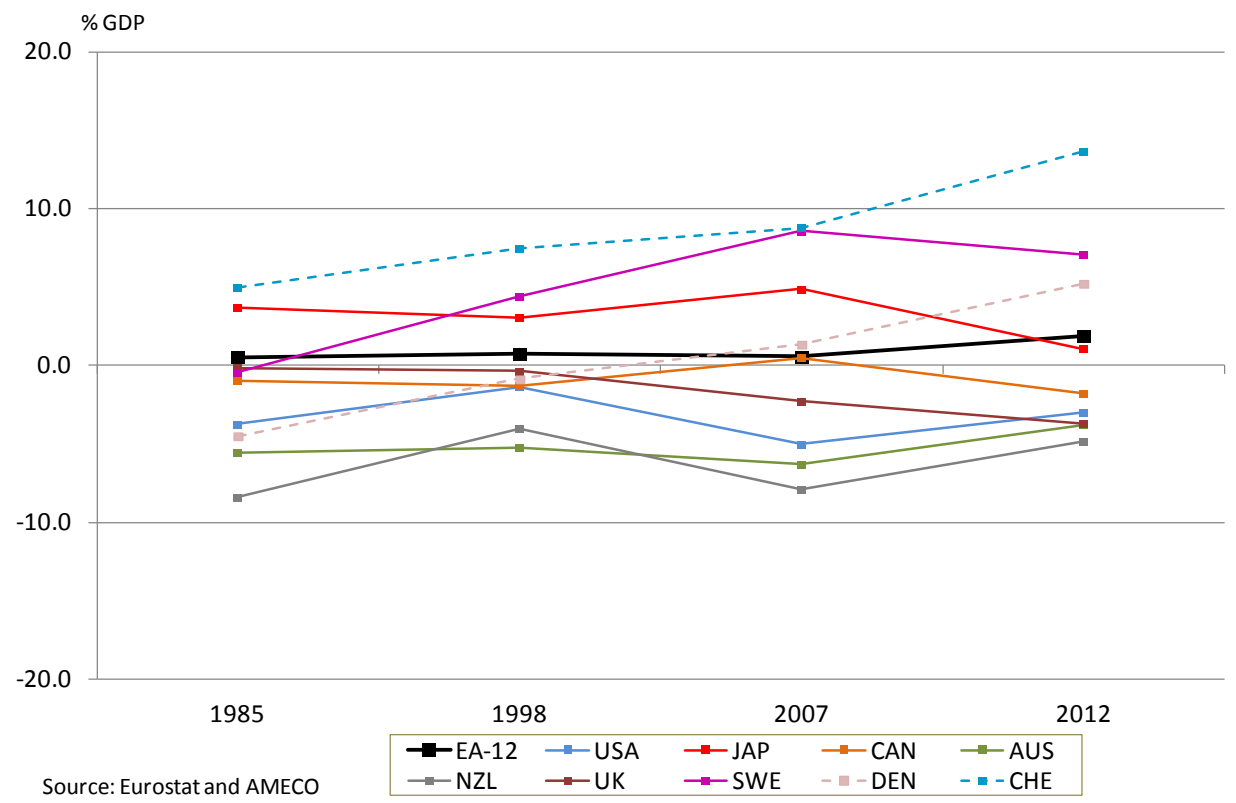

Figure 18.b Evolution of the Current Account (\% of GDP) in Other Developed Countries: Selected Years 


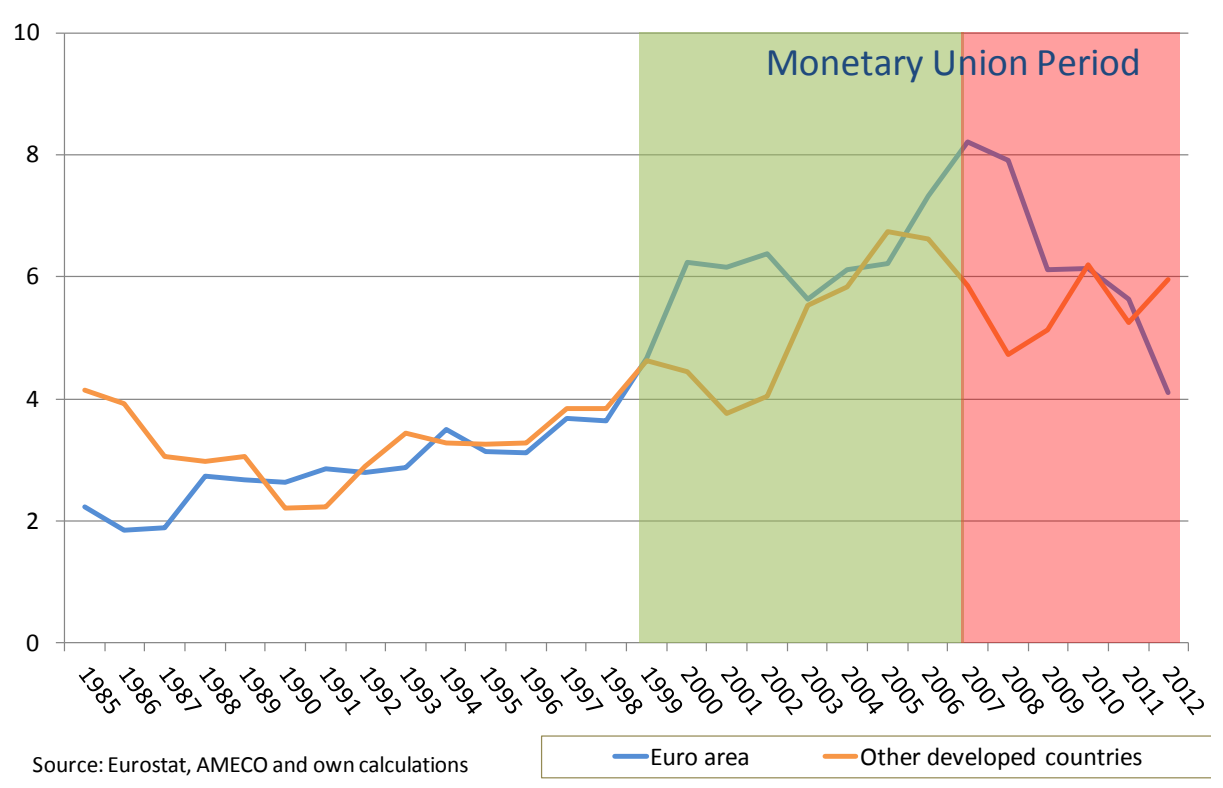

Figure 19. Dispersion of the Current Account

Next we try to explain the evolution of current accounts for both groups of countries and different periods. Conventional candidate explanatory factors include measures of "price competitiveness" and of the cyclical position of the economy. We also explore the role of less conventional non-price measures of competitiveness.

Table 1 presents cross-country regressions of changes in the current account on GDP growth (as a measure cyclical position of the economy), as well as two measures of price competitiveness (the relative price deflator for tradables or relative unit labor costs in the private sector). Specifically, the table shows the results of estimating by OLS different cross-section regressions for the average changes in the current account:

$\Delta \overline{c a}_{i}=\alpha+\beta \Delta \overline{g d p}_{i}+\gamma \Delta \overline{c o m p}_{i}$

where $\Delta \overline{c a}$ stands for the average change in the current account balance over the relevant period, $\overline{g d p}$ is the average growth rate of GDP in that period and $\Delta \overline{c o m p}$ is the percent change in the competitiveness variable. As before, we consider three time periods: pre-EMU (1985-1997); EMU-expanssion (1998-2007) and EMU-recession (2008-2012). The regressions are run separatedly for the euro area countries and other developed countries. 
TABLE 1. CURRENT ACCOUNT DETERMINANTS. Dependent Variable: Change in Current Account $(\triangle C C)$. OLS (robust standard errors)

\begin{tabular}{|c|c|c|c|c|c|c|}
\hline & $\begin{array}{l}1985- \\
1998\end{array}$ & $\begin{array}{l}1998- \\
2007\end{array}$ & $\begin{array}{l}2007- \\
2012\end{array}$ & $\begin{array}{l}1985- \\
1998\end{array}$ & $\begin{array}{l}1998- \\
2007\end{array}$ & $\begin{array}{l}2007- \\
2012\end{array}$ \\
\hline \multicolumn{7}{|c|}{ Euro Area Countries } \\
\hline Intercept & $\begin{array}{c}0.318 \\
(0.119)\end{array}$ & $\begin{array}{l}0.662 \\
(0.104)\end{array}$ & $\begin{array}{l}0.022 \\
(0.288)\end{array}$ & $\begin{array}{l}0.562 \\
(0.080)\end{array}$ & $\begin{array}{l}0.861 \\
(0.334)\end{array}$ & $\begin{array}{l}1.243 \\
(0.120)\end{array}$ \\
\hline GDP growth & $\begin{array}{r}-0.118 \\
(0.041)\end{array}$ & $\begin{array}{c}-0.291 \\
(0.117)\end{array}$ & $\begin{array}{r}-0.619 \\
(0.068)\end{array}$ & $\begin{array}{r}-0.025 \\
(0.021)\end{array}$ & $\begin{array}{c}-0.098 \\
(0.132)\end{array}$ & $\begin{array}{c}-0.274 \\
(0.051)\end{array}$ \\
\hline Tradable prices & $\begin{array}{l}-0.222 \\
(0.034)\end{array}$ & $\begin{array}{l}-0.162 \\
(0.127)\end{array}$ & $\begin{array}{l}-0.149 \\
(0.072)\end{array}$ & - & - & - \\
\hline Unit labor costs & - & - & - & $\begin{array}{l}-0.177 \\
(0.022)\end{array}$ & $\begin{array}{c}-0.414 \\
(0.099)\end{array}$ & $\begin{array}{c}-0.628 \\
(0.065)\end{array}$ \\
\hline Adj. $\mathrm{R}^{2}$ & 0.589 & 0.209 & 0.480 & 0.679 & 0.408 & 0.967 \\
\hline \multicolumn{7}{|c|}{ Other Developed Countries } \\
\hline Intercept & $\begin{array}{l}0.622 \\
(0.204)\end{array}$ & $\begin{array}{l}0.422 \\
(0.430)\end{array}$ & $\begin{array}{l}-0.018 \\
(0.203)\end{array}$ & $\begin{array}{l}0.790 \\
(0.385)\end{array}$ & $\begin{array}{l}0.402 \\
(0.384)\end{array}$ & $\begin{array}{l}0.096 \\
(0.228)\end{array}$ \\
\hline GDP growth & $\begin{array}{l}-0.214 \\
(0.085)\end{array}$ & $\begin{array}{c}-0.151 \\
(0.200)\end{array}$ & $\begin{array}{l}-0.075 \\
(0.388)\end{array}$ & $\begin{array}{l}-0.214 \\
(0.089)\end{array}$ & $\begin{array}{l}-0.130 \\
(0.267)\end{array}$ & $\begin{array}{l}0.055 \\
(0.354)\end{array}$ \\
\hline Tradable prices & $\begin{array}{l}-0.028 \\
(0.033)\end{array}$ & $\begin{array}{c}-0.002 \\
(0.052)\end{array}$ & $\begin{array}{l}0.091 \\
(0.150)\end{array}$ & - & - & - \\
\hline Unit labor costs & - & - & - & $\begin{array}{l}-0.029 \\
(0.037)\end{array}$ & $\begin{array}{r}-0.009 \\
(0.073)\end{array}$ & $\begin{array}{l}0.014 \\
(0.115)\end{array}$ \\
\hline Adj. $R^{2}$ & 0.243 & -0.062 & -0.165 & 0.232 & -0.059 & -0.255 \\
\hline
\end{tabular}

Note: Robust standard errors between brackets. Source: Own calculations.

We discuss some of the main findings. First, for most specifications involving euro area countries there is a significant negative effect of GDP growth on current account. That is, economies in recessions tend to "improve" their current account. That cyclical effect seems to have become stronger during the EMU years. The regressions using data for other developed countries (see bottom panel) also point to a negative effect of economic activity, though the estimated effect is insignificant in all but the pre-EMU specifications.

In the case of euro area countries our estimates also tend to uncover the anticipated negative link between price competitiveness (measured both using relative price of tradables and unit labor costs) and the current account: relative increases in prices tend to be associated with increasing current account 
deficits. ${ }^{12}$ The findings for euro area countries described above do not seem to carry over to our control group of other developed economies: for the latter the relation between external inmbalances and price competitiveness tends to be small or insignificant, once cyclical factors are controlled for.

Going back to the euro area countries, we observe the price effects are on the current account appear to be quantitatively small and weakening over time.

The use of the unit labor costs as the main measure of price competitiveness seems to improve the fit of the regression, specially during the euro-area period. Our results seem to support the conclusion that absent any depreciation in the external value of the euro, the competitiveness problem of some euro area members arises from the inability of members to devaluate, and the correction of the external imbalances calls for a process of internal devaluation. ${ }^{13}$ As we have shown, the level of the relative price of tradable goods does not seem to be the key determinant of existing external imbalances.

Next we broaden the scope of the previous analysis and look at a larger set of factors that could explain the evolution of current account imbalances and its link to competitiveness. What are possible additional dimensions of competitiveness that one may want to incorporate into our analysis? Below we explore the explanatory power of the index of competitiveness constructed by World Economic Forum using a comprehensive set of variables (beyond relative prices or wages), and usually referred to as the Global Competitiveness Index (GCI). ${ }^{14}$ That variable has often been as a tool when thinking about macroeconomic and institutional elements that are critical to understand the determinants of competitiveness and more broadly the growth process. ${ }^{15}$

The GCI is composed of twelve "pillars," all of which are widely accepted as being critical to economic growth. Using a combination of publicly available data and information provided in the Forum's Executive Opinion Survey-

\footnotetext{
${ }^{12}$ Lane (2006) emphasizes the differential impact on the competitiveness of different euro area countries of changes in the external value of the euro, due to the diversity in the composition of trade partners.

${ }^{13}$ Blanchard (2007) constitutes an early analysis on the different options that an euro area country like Portugal had to recover losses of competitiveness.

${ }_{14}$ Several regulation indexes elaborated by the OECD could be used to assess the link between labor market regulation and good market regulations and external imbalances. The Doing Business indicators elaborated by the World Bank can be also used for this purpose. As we discuss below, these aspects constitute key elements of the index elaborated by the World Economic Forum and some of them are assessed to analyze the robustness of our conclusions.

15 This index was elaborated by Xavier Sala-i-Martin and Elsa Artadi and published by the World Economic Forum, and it expands on two previously considered indexes: The Growth Competitiveness Index and Business Competitiveness Index. For more details, see http://en.wikipedia.org/wiki/Global_Competitiveness_Report.
} 
which provides qualitative information on difficult-to-measure concepts - these pillars are brought together into the index. Hence, the index covers aspects such as the quality of the macroeconomic environment, the state of a country's public and private institutions, the increasing importance of technology in the development process, a country's technological readiness, the extent to which the country has a well-developed transport and communications infrastructure network, the quality of education as evaluated by the business community as well as staff's training as a proxy for skill's workers. More importantly, the index also covers goods, labor, and financial markets efficiency and development. ${ }^{16}$

As illustrated in the top line of Table 2, the explanatory power of the overall GCI on current account positions is relatively high, with an $\mathrm{R}^{2}$ of the crosssectional regression around 0.74 in 2007, while 2012 shows a substantial reduction in the explanatory power of the indicator. In addition, although the predictive power of the GCI is no negligible in the case of the group of developed countries in our group of control, the differences are apparent relative to the euro area group. Hence, non-price disparities among euro area play a significantly more important role in explaining current account imbalances among euro area countries.

TABLE 2. $\mathbf{R}^{2}$ OF THE BIVARIATE CROSS-SECTIONAL REGRESSION OF CURRENT ACCOUNT VS. GLOBAL COMPETITIVENESS COMPONENTS.

\begin{tabular}{lcccc}
\hline & \multicolumn{2}{c}{ Euro Area } & \multicolumn{2}{c}{ Other Developed } \\
\hline & 2007 & 2012 & 2007 & 2012 \\
Global competitiveness indicator & 0.74 & 0.46 & 0.27 & 0.38 \\
Pillar 1: Institutions & 0.46 & 0.40 & 0.06 & 0.05 \\
Pillar 2: Infrastructure & 0.36 & 0.33 & 0.36 & 0.17 \\
Pillar 3: Macroeconomic environment & 0.21 & 0.25 & 0.06 & 0.47 \\
Pillar 4: Health and primary education & 0.30 & 0.13 & 0.03 & 0.00 \\
Pillar 5: Higher education and training & 0.58 & 0.28 & 0.05 & 0.13 \\
Pillar 6: Goods markets efficiency & 0.58 & 0.63 & 0.00 & 0.04 \\
Pillar 7: Labor market efficiency & 0.26 & 0.46 & 0.01 & 0.07 \\
Pillar 8: Financial market development & 0.26 & 0.14 & 0.26 & 0.02 \\
Pillar 9: Technological readiness & 0.84 & 0.43 & 0.33 & 0.35 \\
Pillar 10: Market size & 0.07 & 0.05 & 0.01 & 0.12 \\
Pillar 11: Business sophistication & 0.87 & 0.58 & 0.62 & 0.43 \\
Pillar 12: Innovation & 0.69 & 0.37 & 0.45 & 0.42 \\
\hline
\end{tabular}

Source: Own calculations.

16 A brief description of the "pillars" is presented in the Appendix. 
Southern European countries display both low levels of broadly defined competitiveness and large current account deficits. If we give a causal interpretation to that relation, external adjustment would require continued gains in competitiveness, beyond the scope provided by further reductions in wages. To understand how this could be brought about we now turn to the analysis of which pillar or component of the GCI is driving the strong correlation between current account imbalances and competitiveness.

Table 2 also shows the $\mathrm{R}^{2}$ of the pairwise cross sectional regressions between the current account level and each of the components of the GCI. There are four factors that stand out in terms of their explanatory power for current account performance: (i) goods markets efficiency, (ii) technological readiness (i.e., the ability of entrepreneurs to adopt existing technologies to enhance the productivity of its industries), (iii) business sophistication (i.e., the quality of a country's business networks and supporting industries), and (iv) innovation capabilities. Only the three last components explain the bulk of the non-price contribution to current account imbalances among the developed countries included in our group of control.

Table 3 tries to introduce some robustness analysis into the previous exercise. To this end, we ran bivarate regressions of the current account against a series of qualitative and quantitative indicators that have been developed by variaous international institutions aiming at capturing similar aspects of the economy included in the GCI. Factors affecting innovation and R\&D effort and competition in the product market seems to have most of of the explanatory variables. The World Bank indicators of institutional strengh are also very relevant, quite in line with the recent findings by the IMF (2013).

The conclusions seem to be clear and robust across most of the qualitative variables used in our empirical exercises. Our analysis suggests that a comprehensive strategy aimed at reducing and sustain the large current account deficits of some of the euro area countries should include, beyond reduction in wages, structural reforms that help enhance some of the factors above. 


\begin{tabular}{|c|c|c|}
\hline \multicolumn{3}{|c|}{ 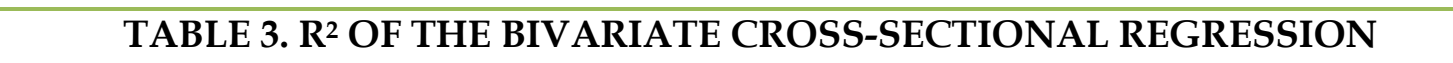 } \\
\hline & 2007 & 2011 \\
\hline Institutions-Rule of law (World Bank, WB) & 0.34 & 0.53 \\
\hline Institutions: Quality of regulation (WB) & 0.43 & 0.72 \\
\hline $\begin{array}{l}\text { Higher education: Population more than } \\
\text { secondary degree (Eurostat) }\end{array}$ & 0.48 & 0.41 \\
\hline $\begin{array}{l}\text { Goods market efficiency: Product Market } \\
\text { Regulation (OECD) }\end{array}$ & 0.41 & 0.42 \\
\hline $\begin{array}{l}\text { Labor market efficiency: Employment } \\
\text { Protection Legislation (OECD) }\end{array}$ & 0.18 & 0.27 \\
\hline $\begin{array}{l}\text { Business sophistication: \% firm with } \\
\text { internet (Eurostat) }\end{array}$ & 0.09 & 0.17 \\
\hline $\begin{array}{l}\text { Technological readiness: } R \& D \text { investment } \\
\text { (Eurostat) }\end{array}$ & 0.37 & 0.32 \\
\hline Innovation: \% innovating firms (Eurostat) & 0.45 & 0.49 \\
\hline
\end{tabular}

Source: Own calculations from different sources.

\section{Conclusions}

We have examined the patterns of convergence and divergence in unemployment rates, inflation, relative prices and current account balances among euro area countries over the past quarter century. A number of observations stand out.

The first nine years of EMU were associated with a strong converge in unemployment rates across euro area countries, a process that was interrupted and reversed during the crisis. A similar process has been underway since 1985 for all advanced economies, not only those in the euro area, being interrupted only by major recessions. However, especially during the last recession the EMU has not prevented a dramatic surge in the dispersion of unemployment rates within the euro area. The fact that the increase in dispersion across euro area countries has been much larger than for non-euro countries is consistent with the hypothesis that the common currency in its initial design and the lack of country-specific monetary policies or stabilizing risk-sharing devices to accommodate country specific shocks may have been a factor behind the large differences in unemployment performance.

Secondly, and despite the persistence of significant inflation differentials, our analysis points to a strong convergence of inflation rates among euro area 
countries. But as in the case of unemployment rate, the evidence suggests that EMU has not been a critical factor behind that convergence. The reason is that the phenomenon of inflation convergence got underway well before the creation of EMU, and has not been restricted to euro area countries. Furthermore, the operation of EMU does not seem to have strengthened or accelerated that convergence, at least in comparison to other developed economies.

Thirdly, rather than generating ever increasing gaps, the pattern of inflation differentials in euro area countries has been associated with a substantial convergence in relative price levels, especially in the case of tradable goods.

Finally, we have argued that variations in current account balances across euro area countries seems to display a small correlation with "narrow" measures of competitiveness, as represented by relative price levels. Instead, they seem to bear a stronger relation with broader, non-price competitiveness factors. It follows that internal devaluation policies may have limited success at reducing external imbalances in the medium run unless accompanied by structural reforms that boost some of those non-price factors. 


\section{References}

Allington, Nigel F.B., Paul A. Kattuman and Florian A. Waldmann, 2005, “One Market, One Money, One Price? Price Dispersion in the European Union," International Journal of Central Banking, vol. 1(3), 73-116.

Andrés, Javier; Eva Ortega, and Javier Vallés, 2008, “Competition and Inflation Differentials in EMU," Journal of Economic Dynamics and Control, 32 (3), pp. 848-874.

Alesina, Alberto, and Robert J. Barro, 2002, “Currency Unions," Quarterly Journal of Economics, 117, 409-436.

Balassa, Bela A., 1964, "The Purchasing Power Parity Doctrine: A Reappraisal," Journal of Political Economy, vol. 72, December, pp. 584-596.

Ball, Laurence and Niahm Sheridan, 2005, “Does Inflation Targeting Matter?," in The Inflation Targeting Debate, ed. by Ben Bernanke and Michael Woodford, p. 249-76, (University of Chicago Press, Chicago, IL).

Blanchard, Olivier, 2007, "Adjustment within the euro. The difficult case of Portugal," Portuguese Economic Journal, Vol. 6(1), pp. 1-21, April.

Blanchard, Olivier and Francesco Giavazzi, 2002, "Current Account Deficits in the Euro Area. The End of the Feldstein Horioka Puzzle?," MIT Department of Economics Working Paper No. 03-05 8 (Cambridge, Massachusetts, MIT).

Blanchard, Olivier and Pierre A. Muet, 1993, "Competitiveness through Disinflation: An Assessment of the French Macroeconomic Strategy," Economic Policy, Vol. 8, No. 16, April, pp. 11-56.

Canzoneri, Matthew, Robert Cumby, Behzad Diva and Gwen Eudey, 1998, "Trends in European Productivity: Implications for Real Exchange Rates, Real Interest Rates and Inflation Differentials," Oesterreichische Nationalbank Working Papers 27 (Austrian Central Bank).

Caselli, Francesco, 2009, "Comment," in The Euro at Ten: Lessons and Challenges, ed. by Bartosz Mackowiak et al., pp. 58-65, (Frankfurt, European Central Bank).

Chen, Ruo, Gian-Maria Milesi-Ferretti and Thierry Tressel, 2012, "External Imbalances in the Euro Area," IMF Working Paper, 12/236 (Washington DC. IMF).

European Central Bank, 2003, "Inflation Differentials in the Euro Area Potential Causes and Policy Implications," (Frankfurt, Germany). 
Engel, Charles and John H. Rogers, 2004, “European Market Integration after the Euro," Economic Policy, vol. 19(39), 347-384.

Giannone, Domenico, Michele Lenza and Lucrezia Reichlin, 2010,: “Business Cycles in the Euro Area," in Europe and the Euro, ed. by Alberto Alesina and Francesco Giavazzi, pp. 141-169, (University of Chicago Press Chicago, IL).

International Monetary Fund, 2013: “2013 Pilot External Sector Report,” IMF Policy Paper, August, (Washington, IMF).

Kalemli-Ozcan, Sebnem, Elias Papaioannou, and José-Luis Peydró, 2010, “What Lies Beneath the Euro's Effect on Financial Integration? Currency Risk, Legal Harmonization or Trade?," Journal of International Economics, vol. 81, 75-88.

Kenen, Peter, 1969, “The Theory of Optimum Currency Areas: An Eclectic View," in Monetary Problems of the International Economy, ed. by Robert A. Mundell and Alexander K. Swoboda, pp. 41-60 (University of Chicago Press Chicago, IL).

Lane, Philip, 2006, "The Real Effects of European Monetary Union," Journal of Economic Perspectives, vol. 20 (4), 47-66.

Mishkin, Frederic, and Klaus Schmidt-Hebbel, 2007, “Does Inflation Targeting Make a Difference?" in Monetary Policy under Inflation Targeting, ed. by Frederic Mishkin and Klaus Schmidt-Hebbel, pp. 291-372 (Chile, Banco Central de Chile).

Mongelli, Francesco-Paolo and Charles Wyplosz, 2009, "The Euro at Ten: Unfulfilled Threats and Unexpected Challenges," in The Euro at Ten: Lessons and Challenges, ed. by Bartosz Mackowiak et al., pp. 24-57, (Frankfurt, European Central Bank).

Mundell, Robert A., 1961, “A Theory of Optimum Currency Areas,” American Economic Review, 51, pp. 657-665.

Samuelson, Paul A., 1964, "Theoretical Notes on Trade Problems," Review of Economics and Statistics, vol. 23.

Santos Silva, Joao M.C. and Silvana Tenreyro, 2010, "Currency Unions in Prospect and Retrospect," Annual Review of Economics, 2, pp. 51-74.

Ruscher, Eric and G.B. Wolf, 2009, "External rebalancing is not just an exporters' story: real exchange rates, the non-tradable sector and the euro," Economic Papers 375, March 2009, ECFIN, European Commission. 


\section{Appendix: Data Sources and Description of the Variables}

Most of the data used in this paper has been obtained from the statistical office of the European Union (Eurostat), at the web site: http://epp.eurostat.ec.europa.eu/portal/page/portal/statistics/themes. In some cases the time series were forward extended using other data basis, such as AMECO (ECFIN European Commission):

http://ec.europa.eu/economy_finance/ameco/user/serie/SelectSerie.cfm and EU-KLEMS: http://www.euklems.net/.

- In particular, the European unemployment rates were obtained from the Labor Force Survey, using the conventional definitions (population aged 15-64):

http://epp.eurostat.ec.europa.eu/portal/page/portal/employment_unemployment_lfs/d ata/database.

On its side, the US unemployment rate corresponds to the household data of the Bureau of Labor Statistics: http://www.bls.gov/news.release/laus.t01.htm.

- The European and other countries inflation rates were obtained from AMECO, and they correspond to the harmonized or domestic concept as available:

http://epp.eurostat.ec.europa.eu/portal/page/portal/statistics/themes.

- GDP, value added and their deflators, employment (heads and hours, total employment and wage earners) and compensation of employees correspond to their National Accounts definitions. These time series were obtained from Eurostat at the web site: http://epp.eurostat.ec.europa.eu/portal/page/portal/national_accounts/data/database

In this respect, the tradable sector corresponds to the NACE activities A to E; the nontradable sector to $\mathrm{F}$ to $\mathrm{E}$.

- The source of the purchasing power parities (PPP) used in the construction of the price levels is also Eurostat and the International Monetary Fund WEO database:

http://epp.eurostat.ec.europa.eu/portal/page/portal/purchasing_power_parities/data/ database

For the euro area countries, the tradable sector is identified with total goods and the nontradable sector with total services. For other developed countries, relative prices of the tradable sector in the base year correspond to those of the GDP.

http:/ / www.imf.org/external/ns/cs.aspx?id=28

- Information on the current account was also obtained from the balance of payments compiled by Eurostat and the International Monetary Fund WEO database:

http://epp.eurostat.ec.europa.eu/portal/page/portal/balance_of_payments/data/databa $\underline{\text { se }}$

http://www.imf.org/external/ns/cs.aspx?id=28

Unit labor costs are defined as the ratio between wages and labor productivity. Wages are obtained by dividing compensation of employees on hours worked by employees. Finally, labor 
productivity corresponds to GDP (Value added) divided on hours worked by total employment.

The Global Competitiveness Index corresponds to the elaboration of the World Economic Forum: http://www.weforum.org/issues/competitiveness-0/gci2012-data-platform/

A brief description of the GCI twelve pillars provided in the main report.

First pillar: Institutions. The institutional environment is determined by the legal and administrative framework within which individuals, firms, and governments interact to generate wealth. Government attitudes toward markets and freedoms and the efficiency of its operations are also very important: excessive bureaucracy and red tape, overregulation, corruption, dishonesty in dealing with public contracts, lack of transparency and trustworthiness, inability to provide appropriate services for the business sector, and political dependence of the judicial system impose significant economic costs to businesses and slow the process of economic development.

Second pillar: Infrastructure. A well-developed transport and communications infrastructure network is a prerequisite for the access of_less-developed communities to core economic activities and services. Effective modes of transport-including quality roads, railroads, ports, and air transport-enable entrepreneurs to get their goods and services to market in a secure and timely manner and facilitate the movement of workers to the most suitable jobs.

Third pillar: Macroeconomic environment. A proper management of public finances is also critical to ensuring trust in the national business environment. This pillar includes indicators capturing the quality of government management of public finances. Running persistent fiscal deficits limits the government's future ability to react to business cycles and to invest in competitiveness-enhancing measures. It is important to note that this pillar evaluates the stability of the macroeconomic environment, so it does not directly take into account the way in which public accounts are managed by the government.

Fourth pillar: Health and primary education. Poor health leads to significant costs to business, as sick workers are often absent or operate at lower levels of efficiency. In addition to health, this pillar takes into account the quantity and quality of the basic education received by the population.

Fifth pillar: Higher education and training. This pillar measures secondary and tertiary enrollment rates as well as the quality of education as evaluated by the business community. The extent of staff training is also taken into consideration because of the importance of vocational and continuous on-the-job training-which is neglected in many economies-for ensuring a constant upgrading of workers' skills.

Sixth pillar: Goods market efficiency. Healthy market competition, both domestic and foreign, is important in driving market efficiency and thus business productivity by ensuring that the most efficient firms, producing goods demanded by the market, are those that thrive. The best possible environment for the exchange of goods requires a minimum of impediments to business activity through government intervention. Market efficiency also depends on demand conditions such as customer orientation and buyer sophistication. For cultural or historical reasons, customers may be more demanding in some countries than in others. 
Seventh pillar: Labor market efficiency. The efficiency and flexibility of the labor market are critical for ensuring that workers are allocated to their most effective use in the economy and provided with incentives to give their best effort in their jobs. Efficient labor markets must also ensure a clear relationship between worker incentives and their efforts to promote meritocracy at the workplace, and they must provide equity in the business environment between women and men.

Eighth pillar: Financial market development. An efficient financial sector allocates the resources saved by a nation's citizens, as well as those entering the economy from abroad, to their most productive uses. A thorough and proper assessment of risk is therefore a key ingredient of a sound financial market. In order to fulfill all those functions, the banking sector needs to be trustworthy and transparent, and-as has been made so clear recently-financial markets need appropriate regulation to protect investors and other actors in the economy at large.

Ninth pillar: Technological readiness. The technological readiness pillar measures the agility with which an economy adopts existing technologies to enhance the productivity of its industries, with specific emphasis on its capacity to fully leverage information and communication technologies (ICT) in daily activities and production processes for increased efficiency and enabling innovation for competitiveness.

Tenth pillar: Market size. Therefore we continue to use the size of the national domestic and foreign market in the Index. Thus exports can be thought of as a substitute for domestic demand in determining the size of the market for the firms of a country.

Eleventh pillar: Business sophistication. The quality of a country's business networks and supporting industries, as measured by the quantity and quality of local suppliers and the extent of their interaction, is important for a variety of reasons. Individual firms' advanced operations and strategies (branding, marketing, distribution, advanced production processes, and the production of unique and sophisticated products) spill over into the economy and lead to sophisticated and modern business processes across the country's business sectors.

Twelfth pillar: Innovation. The final pillar of competitiveness focuses on technological innovation. In particular, it means sufficient investment in research and development (R\&D), especially by the private sector; the presence of high-quality scientific research institutions that can generate the basic knowledge needed to build the new technologies; extensive collaboration in research and technological developments between universities and industry; and the protection of intellectual property, in addition to high levels of competition and access to venture capital and financing that are analyzed in other pillars of the Index.

\section{Sources of the alternative structural indicators used in Table 3.}

Institutions-Rule of law (World Bank, WB):

http://databank.worldbank.org/data/views/variableselection/selectvariables.aspx? source $=\mathrm{w}$ orldwide-governance-indicators

Institutions: Quality of regulation (WB):

http://databank.worldbank.org/data/views/variableselection/selectvariables.aspx? source $=\mathrm{w}$ orldwide-governance-indicators

Higher education: Population more than secondary degree (Eurostat): 
http://epp.eurostat.ec.europa.eu/portal/page/portal/education/data/database

Goods market efficiency: Product Market Regulation (OECD):

http://www.oecd.org/economy/growth/indicatorsofproductmarketregulationhomepage.htm

Labor market efficiency: Employment Protection Legislation (OECD):

http://www.oecd.org/employment/emp/oecdindicatorsofemploymentprotection.htm

Business sophistication: \% firm with internet (Eurostat):

http://epp.eurostat.ec.europa.eu/portal/page/portal/science_technology_innovation/data/d atabase

Technological readiness: R\&D investment (Eurostat):

http://epp.eurostat.ec.europa.eu/portal/page/portal/science_technology_innovation/data/d atabase

Innovation: \% innovating firms (Eurostat):

http://epp.eurostat.ec.europa.eu/portal/page/portal/science_technology_innovation/data/d atabase 